\title{
II. Mahmud Devrinde İdari-Askeri Bir Üs: Rami Kışlası
}

\author{
Yüksel Çelik*
}

\begin{abstract}
An Administrative-Military Headquarter During the Reign of Mahmud II: Rami Barracks
Abstract $~-$ This essay examines the process of transition in the Ottoman military system from Janissary chambers to barrack structures, built for the modern trained regular armies on the European model. In this context, the main focus will be on the construction of the Rami Çiftlik Barrack, which is built for newly established Asakir-i Mansure Army after the Auspicious Event (Vak'a-i Hayriyye) in 1826; also to protect Mahmud II himself from counter-coup attempts of annihilated Janissary corps remaining's. The steps also were taken by Mahmud II to calm the public tension and raising morale of army, fighting against the Russia which is broke out in 1828. The essay analyzes, on the other hand, assuring attempts of Mahmud II against far opposition circles which criticize his radical reforms harshly, also his official acts and everyday life activities in Rami Barrack which he resided 617 days; Meanwhile, the essay tried to evaluate main events that played role in becoming Rami Barrack an interim administrative and military base; likewise important developments occurred in the history of the Rami Barracks after the era of Mahmud II till today.
\end{abstract}

Key words: Barracks, Janissaries, Rami Barrack, Davudpaşa Barrack, Ottoman Architecture, Mahmud II, Asakir-i Mansure Army.

\section{Giriş}

Osmanlı Beyliği kurulduğunda, daimi ve düzenli bir orduya sahip değildi. Gaza ve cihad idealinden beslenen ve sefer esnasında beyin etrafinda toplanan aşiret kuvvetleri ile gönüllü süvarilerden oluşan birliklerin büyük bölümü, savaşın

* Marmara Üniversitesi. 
ardından ganimetten hisselerini alarak işlerinin başına dönerlerdi. Başlangıçta uçbeylerinin önderliğinde; Gâziyân, Ahiyân, Abdalân ve Bâciyân-ı Rûm olarak adlandırılan Bâtınî zümrelerin de desteğiyle yürütülen fütuhat hareketlerinin giderek yoğunlaşmasıyla, sefer esnasında toplanan muvakkat kuvvetlerle bu mekanizmanın işletilmesinin imkânsız olduğu görülmüştür. Doğal olarak bu durum düzenli ve daimi bir ordunun teşkil edilmesini gündeme getirdiğinden, Orhan Gazi zamanında (hd.1324-1362) Çandarlı Hayreddin Kara Halil Paşa’nın teklif ve gayretiyle "yaya" ve "müsellem" (süvari) adı verilen ilk daimi ve düzenli askeri birlikler oluşturulmuştur. Yaya ve müsellemlerin zamanla Rumeli fütuhatında yetersiz kalması nedeniyle askeri teşkilata I. Murad devrinde (hd.1362-1389) acemi ocağı ilave edilmiş ve sonraki dönemlerde de yeniçeri sayısı arttırılmıştı. XVI. yüzyıl ortalarında devlet teşkilatının gelişmesi ve büyümesine paralel olarak kapıkulu ocaklarının kurulmasıyla yaya ve müsellemler geri planda kalmış, kapıkulları imparatorluğun temel askeri sınıfı haline gelmiştir. ${ }^{1}$

XVII. yüzyıl başlarına dek gelişen ve gittikçe güçlenen askeri yapıda zamanla bazı aksaklıklar belirince, bunların giderilmesi yönünde bir takım düzenlemeler yapılmak istenilmiştir. Ancak II. Osman (hd.1618-1622) örneğinde olduğu gibi, müesses nizam ve askeri teşkilatı doğrudan ilgilendiren bu tür ıslahat girişimleri padişahın hayatına mâl olmuştur. ${ }^{2}$ Daha sonra IV. Murad (hd.1623-1640) ve Köprülüler devrinde alınan radikal ve kapsamlı önlemler de idari-askeri alandaki kötü gidişatı engelleyememiştir. ${ }^{3}$

1 Halime Doğru, Osmanlı Imparatorluğu'nda Yaya-Müsellem-Taycı Teşkilatı, XV. ve XVI. Yüzyılda Sultanönü Sancăğ, (İstanbul, Eren Yayınları, 1990); İsmail Hakkı Uzunçarşılı, Kapıkulu Ocakları, I-II, (Ankara: Türk Tarih Kurumu, 1988); Uzunçarşılı, Çandarlı Vezir Ailesi, (Ankara: Türk Tarih Kurumu, 1988); Abdülkadir Özcan, "Osmanlı Askeri Teşkilatı”, Osmanlı Devleti ve Medeniyeti Tarihi, Ekmeleddin İhsanoğlu (ed.), (İstanbul: IRCICA, 1994), I, 337 vd; Ahmed Cevad, Târîh-i Askerî-i Osmâni, (İstanbul: Kırk Ambar Matbaas1, 1299), s. 1-12.

2 Irina Petrosyan, “Osmanlı İmparatorluğu’nda Askeri Reformlar Konusunda İlk Girişim: XVI. Yüzyılın Sonu ile XVII. Yüzyılın Başında Yeniçeri Ocağı”, Osmanlı, Güler Eren (ed.), (Ankara: Semih Ofset, 1999), VI, s. 673-683; Mufassal Osmanlı Tarihi, (İstanbul: Baha Matbaas1, 1960), IV, s. 1818-1834; Feridun Emecen, “Osman II”, Türkiye Diyanet Vakfı İlâm Ansiklopedisi (TDVİA), XXXIII, s. 453-456; Orhan Şaik Gökyay, "II. Osman'ın Şehadeti”, Atsız Armağanı, Erol Güngör vd. (İstanbul: Ötüken Yayınları, 1976), s. 187-256.

3 Uzunçarşıl1, Osmanlı Tarihi, (Ankara: Türk Tarih Kurumu, 1988), III/II. kısım, s. 274282; Rhoads Murphy, "The Functioning of The Ottoman Army under Murad IV (1623-1639): Key to the Understanding of the Relationship Between Center and 
Osmanlı İmparatorluğu'nda XVII. yüzyıl ortalarına kadar zaman zaman aksayarak da olsa fütuhat çarkının bir şekilde dönmesi ve "dâire-i adliyye" olarak tanımlanan idari-ictimai-iktisadi yapıyı bir arada tutan halkaların henüz kopmamış olmasından ötürü, yapısal sorunlar umumiyetle tali meseleler olarak mütalaa edilmiştir. Ancak XVII. yüzyıl sonlarında alınan ağır zincirleme mağlubiyetler, galip tarafın gücünün nereden kaynaklandığı konusunun ciddi bir biçimde sorgulanmasını da beraberinde getirmiş, bu durum Batı'daki askeri, teknik ve stratejik gelişmelerin önceki dönemlere nazaran çok daha fazla önemsenmesine neden olmuştur. XVIII. yüzyıl sonları itibarıyla, güçlü bir imparatorluğun düzenli bir ordudan, bir başka deyişle disiplinli ve talimli askerden geçtiği konusundaki umumi mutabakat, aynı zamanda büyük ve müştemilatlı kışlaların yapımını da gündeme getirmiştir.

\section{Ordugâhtan Kışla Kompleksine}

Kışla, yazın çadırlarda kalan askerlerin kışın topluca barınmaları için yapılan büyük binalara verilen ve "kışlak" kelimesinden galat umumi bir isimdir. Arkeolojik kazılar kışla benzeri yapıların insanlık tarihinin beşiği olarak kabul edilen Mezopotamya medeniyetinde, mevcut olduğunu göstermiştir. Şüphesiz askeri birliklerin teşkil edilmesiyle birlikte bunlara kalacak yerler/barınaklar da inşa edilmeye başlanmış olmalıdır. Dolayısıyla Sümerlerde ve hatta hakkında bilgi sahibi olunmayan daha eski kavimlerde de kışla benzeri yapıların bulunduğunu tahmin etmek güç değildir. III. binyılda Sümer ve Akkadlarla başlayan Mezopotamya uygarlığını zirveye taşıyan Yeni Assur döneminde (1000-610), II. Assur-nasir-apli tarafından yaptırılan başkent Kalhu'da dikdörtgen şeklinde inşa edilen ekal-maşartiler (kışla-saray), kışla yapılarının bilinen/keşfedilen en eski örneği olmalıdır. Genelde yüksek bir tepeye konuşlandırılan ve sur duvarına istinat ettirilen bu tür kışla-saray yapıları (ekal-maşarti) sonraki dönemlerde Dur-Şarrukin, Ninive ve diğer kentlerde de inşa edilmişlerdir. ${ }^{4}$

Roma askeri teşkilatındaki castrium günümüz kışlalarının en erken/primitif örneği olarak değerlendirilebilirler. Plan bakımından kare ya da dikdörtgen biçimindeki castra, bir çukur ve çakılı kazıklarla yapılmış bir metris tarafından

Periphery in Seventeenth Century Turkey", (doktora tezi, Chicago University, 1979);

Ziya Yılmazer, "Murad IV", TDVİA, XXXI, s. 177-183; Mithat Sertoğlu, IV. Murat, (Ankara: T.C. Kültür ve Turizm Bakanlığı, 1987).

4 Veli Sevin, Yeni Assur Sanatı, I, Mimarlık, (Ankara: Türk Tarih Kurumu, 1991), s. 30-40. 
çevrelenirdi. ${ }^{5}$ Romànın ağaç ordugâhlarına karşılık Osmanlılarda özellikle seferler esnasında muvakkaten ordunun kış mevsimini geçirmesi için inşa edilen kışlakların meştâ olarak adlandırıldıkları da bilinmektedir. Osmanlı başkentinde devletin temel muharip piyade sınıfı olan yeniçerilerin barındıkları odalar (kışlalar) mevcuttu. Geniş bir avlu etrafında karşılıklı iki sıra halinde dizili hücrelerden oluşan Odalar, planları itibarıyla medreselere ve Horasan ile Türkistan'daki yaygın konut tiplerine benzerlerdi. Genelde kâgir ve ahşap olarak inşa edilen ve Şehzadebaşı ile Beyazıt arasında yer alan Eski Odalar ve Aksaray Et Meydanı (Meydan-ı Lahm)'ndaki Yeni Odalar yeniçeri kışlaları olarak asırlarca kullanılmıştır. ${ }^{6}$

XVIII. yüzyılda alınan zincirleme yenilgiler nedeniyle askeri alandaki reform ihtiyacının daha da şiddetli hale gelmesiyle, III. Selim döneminde kurulan alternatif Nizam-1 Cedid Ordusu için modern manada ilk kışla kompleksi olarak kabul edilen Selimiye Kışlası inşa edilmiştir. ${ }^{7}$ Batı tarzında yeni kışlaların inşası ve yaygınlaştırılması hususunda II. Mahmud döneminde çok daha önemli gelişmeler kaydedilmiştir. Bu dönemde Asâkir-i Mansûre-i Muhammediyye Ordusu için inşa edilen veya genişletilen Davudpaşa Sarayı ${ }^{8}$ ve Râmî Çiftliği kışlaları ile akabinde merkez ve taşrada inşa edilen diğer kışlalar, devlet otoritesini simgeleyen yeni yapılar olarak geleneksel mimariden ayrılan tasarımları, üslup özellikleri ve yapım teknikleriyle imparatorluğun Batı'ya dönük yüzünü, keza iktidar ve istikrar idealini temsil etmişlerdir.?

5 Ayşe Y. Kubilay, "Kışlalar", Dünden Bugüne İstanbul Ansiklopedisi (DBİA), (İstanbul: Tarih Vakfı Yayınları, 1994), V, s. 7.

6 A. Süheyl Ünver, "Yeniçeri Kışlaları", Belleten, XL/160 (Ekim 1976), s. 589-601; Yeniçeri Kışlaları, (İstanbul: Şehremaneti Matbaası, 1929); Necdet Sakaoğlu, "Eski Odalar", DBIA, III, s. 203-204; Sakaoğlu, "Yeni Odalar", DBİA, VII, s. 467-468; Ayşe Yetişkin Kubilay, "Kışlalar", DBİA, V, s. 7; Kemal Beydilli, "Yeniçeri”, TDVİA, XLIII, s. 450-462; Mücteba İlgürel, "Yeniçeriler”, İslam Ansiklopedisi (İA), XIII, s. 385-395; Uzunçarşı11, Kapıkulu Ocakları, I, s. 240-247.

7 M. Gözde Ramazanoğlu, "Osmanlı Yenileşme Hareketleri İçerisinde Selimiye Kışlası ve Yerleşim Alanı”, (doktora tezi, Yıldız Teknik Üniversitesi, İstanbul 2003). İlk modern kışla yapısının Cezayirli Hasan Paşa tarafından Hasköy’de yaptırılan Kalyoncu Kışlası olduğu da ileri sürülmüştür (Ayşe Y. Kubilay, "Kışlalar", $D B \dot{I} A$, V, s. 8).

8 Zühal Çetiner Doğdu, "Davutpaşa Kışlası ve İstanbul Kışlaları İçindeki Yeri”, (yüksek lisans tezi, Yıldız Teknik Üniversitesi, İstanbul, 1996); Faruk Tuncer, "Davut Paşa Kışlası Yapilar1", EJOS, IV (2001), Proceedings of the 11th International Congress of Turkish Art, Utrecht-Nederlande, (August 23-28, 1999/XLIII), s. 1-24.

9 Aynur Çiftçi-Nadide Seçkin, "19. Yüzyılda İstanbul'da İnşa Edilen Askeri Yapıların Koruma Sorunları”, Yıldız Teknik Üniversitesi Mimarlık Fakültesi e-Dergisi, I/1 (2005), s. 52. 
Osmanlı İmparatorluğu'nda kışla kavramı ve mimarisini çok genel hatlarıyla iki kategoride ele almak mümkündür. Bunlardan ilki unsurları itibarıyla modern kışla kavramı ile pek de örtüşmeyen ancak fonksiyonları bakımından kışla işlevi gören ordugâh tarzı yerleşmelerdir. Türklerin göçebe geçmişleri ve yaşam felsefeleriyle de ilişkilendirilebilecek bu durum ${ }^{10}$ genelde ordunun sefere çıkışı, uğurlanması ve uzun süren seferlerde barınması için kurulan çadırlar ile bir takım barınak ve barakalardan ibaret muvakkat yerleşmelerdi. Osmanlılarda Rumeli koluna/batı istikametine yapılacak seferlerde Otağ-1 hümayun ve ordugâh Davudpaşa Sahrası'na, Anadolu Kolu/doğu istikametine sefer kararı alındığında ise ordugâh Üsküdar Doğancılar Meydanı'na kurulurdu. ${ }^{11}$ Ordu ve maiyetin niceliğine bağlı olarak sayısız çadırdan ve "halvet bezleri" ile oluşturulan zukaklardan (sokak) müteşekkil bu Çadırlı Ordugâhlar (kışlalar) muvakkaten hizmet verir, merkez ordusu sefere uğurlandıktan sonra barakalar kaldırılır ve çadırlar sökülerek Mehterhâne’ye iade edilirdi. Buna karşın seferdeki birlikler için kurulan ordugâhlar çok daha uzun süreli hizmet verirdi. İkinci kategori ise ilki XVIII. yüzyıl sonlarında III. Selim devrinde ahşap olarak inşa edilen Levend Çiftliği ve Selimiye kışlaları ile başlayan, II. Mahmud devrinde 1826'da yeniçeri ocağının ilgasıyla yerine kurulan Asâkir-i Mansûre Ordusu için yeniden inşa edilen Râmî Kışlası, Davudpaşa Kışlası ve diğerleri ile sayıları hızla arttırılan bugünkü anlamdaki fonksiyonel kışla kompleksleriydi.

Kışla mimarisi incelendiğinde bu tür yapılarda askerlerin sadece barınmadığı, eğitimlerin icrası için talimgâhların, dini vecibelerin ifası için bir takım hususi mekânların inşa edildiği, başta temizlik olmak üzere gündelik ihtiyaçlarını karşılayabilecekleri yerler olarak hamam, firın ve mutfaklar, sağlık hizmeti verilmesi için hastaneler, hayvanlar için büyük ahırlar ve malzemelerin muhafazası için depoların ve sundurmaların da bu yapılar içinde yer aldıkları görülmektedir. Bundan başka padişahların kışlaları ziyaretlerinde kalacakları hususi mekânlar olarak bir hünkâr kasrı ve içinde yine hünkâr mahfili bulunan ve Cuma Selamlığı ifasına elverişli birer camiin yer aldığı görülmektedir.

10 Sir Adolphus Slade (Müşavir Paşa), Türkiye ve Kırım Harbi, çev. Ali Rıza Seyfi, (İstanbul: Genelkurmay X. Şube Yayınları, 1943), s. 211-212. Müşavir Paşa bu konuda bizzat kendi müşahedelerine istinaden ilginç tespitler aktarmış ve "İstanbul'da her şeyin insana ordugâh fikri verdiğgini, sıradan halkın ordugâhtaki askerler gibi yaşadı̆̆ını ve davrandı̆̆ını" ifade etmiştir.

11 Uzunçarşıl1, Kapıkulu Ocakları, I, 367. 
XVIII. yüzyıl sonlarında inşasına başlanan kışla kompleksleri Türk mimarisine yeni bir zihniyet ve plan tipi getirmiştir. Bu kışlalar yeniçeri odalarından tamamen farklı planları, sayıca fazla oluşları, yurt sathına yayılmış bulunmaları ve umumiyetle başlangıçta kâgir daha sonra da taş binalar şeklinde inşaları bakımından farklılık arz etmişlerdir. Bununla birlikte ilk kışla kompleksleri, eski ordugâh geleneğini andırır tarzda sur dışında, rakım olarak yüksek mevkilerde umumiyetle çiftlikler, büyük bahçeler veya sultanlara ait hasbahçelerin hemen yanı başında dikdörtgen planlı, iki katlı ve orta avlulu olarak inşa edilmişlerdir. Kışlaların planları incelendiğinde, uzun koridorların bir tarafına dizilmiş dış avluya bakan koğuşlardan ve bazı ek hizmet birimlerinden oluştukları görülür; orta avluya bakan koridorlar genelde simetrik pencerelerle aydınlatılmıştır. Dış cephede dahi söz konusu simetrinin bozulmamasına hassasiyet gösterilmiş olması bir diğer hususiyettir. ${ }^{12}$

$\mathrm{Bu}$ dönemde inşa edilen kışlalarda biçim açısından genelde neoklasik, kolossal, neobarok ve rönesans üslubu hâkimdir. İnşa edildikleri devre göre hayli hacimli ve görkemli yapılar olan bu kışlalar, umumiyetle şehir merkezinin biraz dışına ya da hemen mücavir alanına inşa edildiklerinden ve yeni yerleşimleri de beraberinde getirdiklerinden daha önce idari olarak Eyüp, Üsküdar, Galata ve nefs-i İstanbul olarak anılan bölgeler arasındaki sınırların birbirine yakınlaşmasına ve hatta bütünleşmesine yol açmışlardır. Diğer bir ifadeyle kışlalar, başta payitaht İstanbul olmak üzere inşa edildikleri şehirlerin fiziki çehresini, yerleşim düzenini ve alanını, keza peyzaj ve siluetini de değiştirmişlerdir. ${ }^{13}$

\section{Râmî Çiftliği Kışla-i Hümayunu'nun İnşası}

Râmî semti, fetihle birlikte kurulan ilk Osmanlı-Türk yerleşmelerinden biri olan Eyüp'ün bir alt iskân birimidir. Eyüp ilçesinin kuzeybatı ucunda yer alan semtte Fatih döneminden itibaren bir takım köy ve mahalleler kurulmuştu. Daha sonra XVIII. yüzyıl başlarında Râmî Paşa Çiftliği olarak da anılacak bu bölgenin, Hamidiye karyesi namıyla Eyüp Kazası’na tabi Küçükçekmece nahiyesine bağlandığı bilinmektedir. ${ }^{14}$ Evliya Çelebi Rumeli'ye sefere giden ordunun bu bölgede

12 Zuhal Çetiner Doğdu, "Kışla Mimarisi”, Türkler, H.C. Güzel, K. Çiçek, S. Koca (ed.), (Ankara: Yeni Türkiye Yayınları, 2002), XII, s. 179-180.

13 Kubilay, "Kışlalar", $D B \dot{I} A$, V, s. 8; H. Fahrunnisa (Ensari) Kara, "Râmî", DBİA, VI, s. 305 .

14 Kara, "Râmî", DBİA, VI, s. 305. 
konakladığını ve civarda bulunan Topçular Mahallesi'nin isminin de burada sefer için son hazırlıklarını ikmal eden topçu birliklerinden ve bir takım top dökümhanelerinden geldiğini kaydetmektedir. ${ }^{15}$ XVIII. yüzyılda başta Râmî Çiftliği olmak üzere bu bölgede yer alan büyük çiftliklerde, daha ziyade Bulgar ve Ermeni çiftçiler çalışmakta ${ }^{16}$ ve bölge Râmî karyesi olarak anılmaktaydı. ${ }^{17}$ XIX. yüzyıla değin Davudpaşa Sarayı, Kâğıthane, Fenerbahçesi ve Kavak Sarayı çevresi gibi Râmî Çiftliği de Bostancıbaşının görev ve sorumluluk alanında olmuştur. ${ }^{18}$

Yukarıda da değinildiği gibi, Osmanlılarda Rumeli koluna/batı istikametine yapılacak seferlerde Otağ-ı hümayun ve ordugâh Davudpaşa Sahrası'na, Anadolu koluna/doğu istikametine sefer kararı alındığında ise ordugâh Üsküdar Doğancılar Meydanı'na kurulurdu. ${ }^{19}$ Bu sebeple Râmî Çiftliği ve Davudpaşa Sarayı civarında ordunun nihai hazırlıklarını tamamlamasına imkân veren ve askerlerin muvakkaten barınabileceği bir takım hizmet birimleri mevcut olmakla birlikte, bunların modern kışla yapıları kapsamında değerlendirilmesi mümkün değildir. ${ }^{20}$

Bazı çalışmalarda Râmî Kışlası’nın II. Mustafa devrinde (hd.1695-1703) reisülküttaplık ve sadrazamlık yapan Râmî Mehmed Paşa tarafından inşa ettirildiği ifade edilmekte ${ }^{21}$ ise de bu doğru değildir. Gerçekte II. Mustafa devrinde burada ilk askeri yapıların inşa edildiği doğrudur, ancak inşa ettiren Râmî Mehmed Paşa değil bizatihi devletti. Söz konusu yapılar kışla hüviyetinden çok sefere çıkacak

15 Evliya Çelebi Seyahatnamesi: Istanbul, Y. Dağl1-S.A. Kahraman (haz.), (İstanbul: Yap1 Kredi Yayınlar1, 2004), I/1, s. 354.

16 P. Ğ. İncicyan, XVIII. Astrda İstanbul, H. Andreasyan (çev.), (İstanbul: Baha Matbaası, 1976), s. 93n.

17 Osman Nuri Ergin, Mecelle-i Umur-ı Belediye, (İstanbul: İstanbul Büyükşehir Belediyesi Yayınlar1, 1995), II, s. 786.

18 Mustafa Nuri Paşa, Netâyicüll-Vukûât, Neşet Çağatay (haz.), (Ankara: Türk Tarih Kurumu Yayınları, 1992), III-IV, s. 122; Ergin, Mecelle-i Umûr-ı Belediyye, II, s. 871.

19 Uzunçarş1l, Kapıkulu Ocakları, I, s. 367.

20 A. Cevad, Târih-i Askerî-i Osmânî, İÜ, TY, nr. 4178, II/IV, 6: "Sultân Selim-i Şehîd Selimiye Kışlasinı tẻsîs ve inşâ etmiş iken yeniçeriler ihrâk-ı bi’n-nâr etmiş idi. Râmî ve Davudaşa cihetlerinde ise aslında kışla yok idi. Bunların 1241'de inşâsına başlanmıştır". Soğanağa Camii İmamı Hafız Mehmed Efendi de günlüğünde Rumeli'ye sefere çıkacak ordunun son hazırlıklarını yaptığı iki mıntıka olarak buralardan kışla olarak değil, Davudpaşa Sarayı ve Râmî Çiftliği olarak bahsetmekte ve 1810 yazında tamir edildiklerini kaydetmektedir [Kemal Beydilli, Osmanlı Döneminde İmamlar ve Bir Imamın Günlü̈̆̈̈, (İstanbul: Tarih ve Tabiat Vakfı Yayınları, 2001), s. 135].

21 Pars Tuğlacı, Osmanl Mimarlı̆̆ında Batılılaşma Dönemi ve Balyan Ailesi, (İstanbul: İnkılap ve Aka, 1981), s. 35; Doğdu, "Kışla Mimarisi", Türkler, XII, s. 181. 
ordunun nihai ihtiyaçlarını karşılayacak lojistik destek ve hizmet birimlerinden ibaretti. Üstelik bu döneme ait kroniklerde, buradaki askeri yapılardan Râmî Kışlası şeklinde bahsedilmemektedir. Bir diğer önemli husus, sanıldığının aksine söz konusu askeri yapıların, Râmî Paşa Çiftliği olarak adlandırılan büyük bahçenin/ çiftliğin içinde değil, hemen yanı başında bulunmasıydı. ${ }^{22}$

Bu bölgedeki askeri yapılaşmayı III. Mustafa (hd.1757-1774) devrine götüren araştırmacılar da mevcuttur. ${ }^{23}$ Yukarıda da işaret edildiği üzere buradaki askeri yapılaşma II. Mustafa devrinde başlamış, Rumeli koluna sefere çıkan ordunun ihtiyaçlarını karşılamak üzere Davudpaşa Sarayı civarındaki askeri yapılaşmaya paralel olarak giderek önem kazanmış ve neticede aşağıda detaylı olarak bahsedileceği üzere II. Mahmud devrinde mevcut yapılar tamir edildiği gibi yeni bir kışla inşa edilmiştir. II. Mustafa devrinde Râmî Paşa Çiftliği civarında inşa edilen yeni binalarla genişletilen askeri yapılar, daha sonra III. Mustafa devrinde Koca Râgıb Paşa’nın sadaretinde (1757-1763) elden geçirilmiş ve bir takım ek hizmet ve lojistik birimleri ilave edilmiştir.

Râmî Kışlası adını II. Mustafa döneminde reisülküttaplık, ardından da sadrazamlık yapan Râmî Mehmed Paşa’nın (1655-1708) bu bölgedeki çiftliğinden almışır. ${ }^{24}$ Sadaretinde patlak veren ve Edirne Vakası (1703) ${ }^{25}$ olarak adlandırılan isyan esnasında önce Edirne'de II. Bayezid evkafı kâtibi Çinici-zâde Ahmed Efendi'nin evinde, ardından da Eyüp'te kendi adıyla anılan çiftliğinde saklanarak asilerin elinden kurtulmuştu. ${ }^{26}$ Devrin kaynaklarından anonim bir tarihte verilen bilgiye göre Edirne Vakası'ndan sonra ortalığın durulması ve yaşanan taht değişikliğinin ardından kendisine ait saray, ${ }^{27}$ konaklar ve çiftliklerine el konulmuş-

22 Abdülhak Molla, Târih-i Livâ, -Sultan II. Mahmud Portresinden Farklı Bir Kesit-, Mehmet Yıldız (haz.), (Ankara: Türk Tarih Kurumu, 2013), s. 3, 13-14, 22, 33, 44, 98, 100, 114-115. Abdülhak Molla bu hususa değindikten sonra zaman zaman padişahın dinlenmek için bu çiftliği tercih ettiğini ifade etmiştir.

23 Ayşe Yetişkin Kubilay, "Râmî Kışlası", DBİA, VI, s. 306.

24 Recep Ahıshalı, "Râmi Mehmed Paşa”, TDVİA, XXXIV, s. 449-451; Uzunçarşılı, Osmanlı Tarihi, IV/II, s. 263-271; Bekir Sitkı Baykal, "Râmî Mehmed Paşa", $\dot{I} A$, IX, s. 623-624; İsmet Parmaksızoğlu, "Râmî Mehmed Paşa", Türk Ansiklopedisi, XXVII, s. 220; Sadettin Nüzhet, Râmî Paşa Hayatı ve Eserleri, (İstanbul: Kanaat Kütüphanesi, 1933).

25 Abdülkadir Özcan, "Edirne Vakası”, TDVIA, X, s. 445-446.

26 Defterdar Sarı Mehmed Paşa, Zübde-i Vekāyi ât, Abdülkadir Özcan (haz.), (Ankara: Türk Tarih Kurumu, 1995), s. 835.

27 Topkapı Sarayı Müzesi Arşivi, (TSMA), nr. E. 7751. Belgede; II. Mustafa'nın yerine III. 
tu. Söz konusu eserde, elinde sadece küçük bir hanenin kaldığı ifade edildiğine göre, ${ }^{28}$ ismiyle anılan çiftlik de bu esnada müsadere edilmiş olmalıdır. Bu çiftlik daha sonra Nevşehirli Damad İbrahim Paşa’nın damadı Kethüda Mehmed Paşa tarafından satın alınmışsa da ${ }^{29}$ Râmî Paşa Çiftliği adıyla anılmaya devam etmiştir.

Emlak-1 hümayundan olan Râmî Çiftliği 1760’lı yıllarda, Hîbetullah ve Şah sultanlara temlik edilmiştir. ${ }^{30}$ Padişahların biniş-i hümayun olarak adlandırılan saray dışı saltanat gezilerinde maiyetleriyle uğradıkları yerler arasında bulunan Râmî Çiftliği'ne, II. Mahmud devrinde Şubat 1815'te hünkârın Üsküdar'daki av tazıları nakledilmiş ve barınmaları için bir takım barakalar inşa edilmiştir. ${ }^{31}$ Daha sonra Kasım 1836'da Darphane-i Amire'ye devredilen Râmî Çiftliği, Müderris Çiftliği ile birlikte II. Mahmud'un kızı Mihrimah Sultan ile evlenen Damad Mehmed Said Paşa'ya temlik edilmiştir. ${ }^{32}$

Râmî Paşa Çiftliği sonraki dönemlerde de padişahların uğrak yerleri olmuştur; mesela I. Abdülhamid (hd.1774-1789); Levent, Topçular ve Râmî çiftlikleri civarında bulunan askeri birliklerin talimlerini, küçük çaplı tatbikatların izlemek ve teftiş etmek amacıyla adı geçen yerleri sık sık ziyaret etmiştir. ${ }^{33}$ Yine Sadrazam Halil Hamid Paşa örneğinde olduğu gibi, azledilen (31 Mart 1785) ve haklarında sürgün kararı verilen bazı devlet adamları, menfasına sevk edilmek üzere Râmî Paşa Çiftliği'ne sevk edilmekteydi. ${ }^{34}$ III. Selim döneminde de biniş-i hümayunlar için Râmî Çiftliği'ne gidildiği görülmektedir. ${ }^{35}$ Soğanağa Camii imamı Hafız Mehmed Efendi'nin cerîdesinden 1810 Haziranında, II. Mahmud'un saltanatının başlarında Rumeli'de Rus ve Sırplarla yapılan savaş esnasında Râmî Çiftliği’ndeki askeri yapıların Davudpaşa Sarayı civarındaki yapılarla birlikte esaslı bir

Ahmed tahta çıktığında Râmî Mehmed Paşa’nın Zeyrek Camii civarındaki sarayının müsadere edilerek padişahın kızı Ayşe Sultan’a temlik edildiği ifade edilmektedir.

28 Anonim Osmanlı Tarihi (1099-1116/1688-1704), Abdülkadir Özcan (haz.), (Ankara:

Türk Tarih Kurumu, 2000), s. 247.

29 Uzunçarşılı, Osmanlı Tarihi, IV/II, s. 270.

30 Başbakanlık Osmanlı Arşivi (BOA), Cevdet Saray (C. SM), nr. 23/1192.

31 BOA, Ali Emiri (AE), II. Mahmud, nr. 1110; C. SM, nr. 37/1855.

32 BOA, C. SM, nr. 106/5309.

33 Fikret Sarıcaoğlu, Kendi Kaleminden Bir Padişahın Portresi, Sultan Abdülhamid (17741789), (İstanbul: Tarih ve Tabiat Vakfi, 2001), s. 50.

34 Taylesâni-zâde Hafız Abdullah Efendi Tarihi, İstanbul'un Uzun Dört Yılı (1785-1789), yay. Feridun M. Emecen, İstanbul 2003, I, 63.

35 Taylesâni-zâde Hafız Abdullah Efendi Tarihi, I, 55, 417. 
biçimde elden geçirildiği anlaşılmaktadır. ${ }^{36} \mathrm{Bu}$ iş tamamlandıktan sonra Ağustos 1810 'da Rumeli cephesine gidecek orduyu uğurlamak için Davudpaşa sahrasına giden II. Mahmud bazı geceler Râmî Çiftliği’nde kalmıştır. ${ }^{37}$

Osmanlı ordusunun bel kemiği kapıkulu ocakları ve özellikle de bunun en önemli unsuru olan yeniçeri ocağı, kuruluşundan XVI. yüzyılın sonlarına dek mütemadiyen gelişmiş ve önemli hizmetler ifa etmişti. Ancak XVII. yüzyılla birlikte; padişahların seferlere iştirak etmekten vazgeçmeleri, iltizam, iltimas ve himaye ile ocağa kanun ve teamüllerin dışında asker alınması, makam ve mevki hırsıyla vezirler ile ocak ağalarının kendi emelleri doğrultusunda yeniçerileri isyana teşvik etmeleri gibi nedenler ocak nizamını tamamen yozlaştırmıştı. ${ }^{38} \mathrm{I}$. Mahmud (hd.1730-1754) ve III. Mustafa (hd.1757-1774) dönemlerinde reform girişimlerinden beklenen sonuçların elde edilememesi ve özellikle III. Selim devrinde (hd.1789-1807) Nizam-1 Cedid denemesinin fiyaskoyla sonuçlanması ve padişahın katli, yeniçeri ocağının ıslahı yönünde reformist çevrelerde ciddi bir ümitsizlik ve teslimiyet hali yaratmıştır. Son saray baskınından yaralı olarak kurtulan ve durumun ciddiyetinin farkında olan II. Mahmud'un (hd.1808-1839) ihtiyatlı ve tedbirli bir hazırlık aşamasından ve nihayet Eşkinci Ordusu denemesinden de bir sonuç alınamayacağının anlaşılmasından sonra 17 Haziran 1826 'da Vak'a-i Hayriyye olarak adlandırılan bir iç savaşla yeniçeri ocağı ilga edilmiştir. ${ }^{39}$

36 Beydilli, Osmanl Döneminde İmamlar ve Bir Imamın Günlüğ̈̈, s. 135.

37 Cabi Ömer Efendi, Câbi Tarihi, Mehmet Ali Beyhan (haz.), (Ankara: Türk Tarih Kurumu, 2003), I, s. 658. Cabi Ömer Efendi orduyu uğurlamaya giden padişahın askerler sefere çıkmadan Suriçi'ne girmelerinin teamüllere aykırı olduğunu belirttikten sonra, Râmî Çiftliği'nin Valide Sultan'a tahsis edildiğini, padişahın ise Eyüp’te bulunan Esma Sultan Sarayı, diğer sultan sarayları ve bazen de Râmî Çiftliği'nde gecelediğini, sabahları da Davudpaşa sahrasına gidip ordunun son hazırlıklarını teftiş ettiğini nakletmiştir.

38 Ahmed Cevad, Târîh-i Askerî-i Osmânî, I, İstanbul 1299; Sahaflar şeyhi-zâde Esad Efendi, Üss-i Zafer, (İstanbul: Süleyman Efendi Matbaası, 1293), s. 8 vd; Ahmed Lütfi, Tarih, (İstanbul: Matbaa-i Amire, 1290), I, s. 124 vd; Kâmil Paşa, Târîh-i Siyâsî-i Devlet-i Aliyye-i Osmâniyye, (İstanbul: Matbaa-i Ahmed İhsan, 1327), III, s. 96 vd; Uzunçarşıll, Kapıkulu Ocakları, I, s. 477vd; Godfrey Goodvin, Yeniçeriler, Derin Türkömer (çev.), (İstanbul: Doğan Kitap, 2001); Mustafa Akdağ, "Yeniçeri Ocak Nizamının Bozulması", AÜDTCF. Dergisi, V/3(1947), s. 295-300; İrina Petrosyan, "Osmanlı İmparatorluğunda Askeri Reformlar Konusunda İlk Girişim: XVI. yy. Sonu ile XVII. yy. Başında Yeniçeri Ocă̆ı", Osmanl, VI, s. 673-683; Mücteba İlgürel, "Yeniçeriler”, $\dot{I A}$, XIII, s. 385-395; Abdulkadir Özcan, "Osmanlı Askeri Teşkilatı", Osmanlı Devleti Tarihi, ed. E. İhsanoğlu, (İstanbul: IRCICA, 1994), I, s. 356-359.

$39 \mathrm{Bu}$ sürecin ayrıntıları için bkz. Yüksel Çelik, Şeyhü'l-Vüzerâ Koca Hüsrev Paşa-II. Mahmud Devrinin Perde Arkası, (Ankara: Türk Tarih Kurumu, 2013), s. 251-268. 
Yeni kurulan Asâkir-i Mansûre Ordusu'nun vezir rütbesindeki en rütbeli subayı olan seraskerin komutasında hizmet edecek iki alayın Beyazıt'taki Serasker Kapısı'nda (Bâbıseraskerî), üçünün Davudpaşa Sarayı civarında, diğer üçünün de Üsküdar Selimiye'de konuşlandırılması kararlaştırılmıştır. Öte yandan Kasım 1808'deki yeniçeri isyanı esnasında Levend Çiftliği ve çevresindeki diğer Nizam-1 Cedid binalarıyla birlikte asiler tarafından yakılmış olan Selimiye Kışlası' nın ${ }^{40}$ hemen tamirine ve Davudpaşa Sarayı ile Râmî Çiftliği’nde konuşlandırılacak talimli askeri birlikler için ise mevcut yapıların elden geçirilmesine ve birer yeni kışlanın inşasına karar verilmişti. ${ }^{41}$

Vak'a-i Hayriyye esnasında, yeniçeri kışlaları olan Eski Odalar ile Yeni Odalar yakılıp yıkıldığından, başkentte askerlerin barınabileceği mekânlar mevcut değildi. ${ }^{42}$ Yeni askeri teşkilatın oluşturulması telaşının oldukça yoğun olduğu 1826 yazında, Seraskerlik makamı olarak belirlenen Saray-1 Atîk-i Âmire'de (Eski Saray) ikamet eden saray görevlileri ve cariyelerin tahliyesinden sonra burada yer alan büyük ahşap ve kâgir konaklarda alelacele bir takım tadilat yapılmış ve Mansûre Ordusu'na yazılan neferlerin bir kısmı buralara yerleştirilmişlerdi. ${ }^{43}$

Asâkir-i Mansûre Ordusu için yeni kışlaların inşası yönünde karar alındığında, Eyüp’te yapılması öngörülen kışlanın başlangıçta Kâğıthane civarındaki

40 Georg Oğulukyan'in Ruznamesi, 1806-1810 İsyanları-III. Selim, IV. Mustafa, II. Mahmud ve Alemdar Mustafa Paşa,: Hrand D. Andreasyan (çev. ve notlar), (İstanbul: Edebiyat Fakültesi Basımevi, 1972), s. 44-45.

41 Ahmed Cevad, Târih-i Askerî-i Osmâni, İstanbul Üniversitesi Tarih Yazmaları, nr. 4178, c. II/IV. kitap, s. 6; Lütfi, Tarih, I, s. 148. Selimiye Kışlası'nın tamiratı ve genişletilmesi 26 Ocak 1829'da tamamlanmış ve Hüsrev Paşa'nın da hazır bulunduğu bir törenle açılmıştır (Cevad, Tarih-i Askerî, II, s. 144). Bu tür tadilat çalışmaları daha sonra da tekrarlanmıştır (BOA, C. AS, nr. 45571; 37510; Mehmed Dâniş, Netîcetü'l-Vekāyi“, Şamil Mutlu (haz.), İstanbul 1994, s. 68, 71-72, 191-204; Mufassal Osmanl Tarihi, V, s. 2894; A. Özcan, "Osmanlı Askeri Teşkilatı", s. 457; Zuhal Çetiner Doğdu, "Kışla Mimarisi”, Türkler, XII, s. 178-189).

42 A. Cevad, Târih-i Askerî-i Osmânî, İÜ, TY, nr. 4178, II/IV, s. 6-7. Vak’a-i Hayriyye esnasında Aksaray'daki Yeni Odalar top atışları ve yağlı paçavralarla yakılmış, Şehzadebaşı ve Beyazıt arasındaki Eski Odalar ise ocağın ilgasından birkaç gün sonra yıktırılmıştır, Bununla da yetinilmeyerek Eski Odaların bulunduğu bölgeye Fevziye, Yeni Odaların bulunduğu mevkie de Ahmediye denilmesi kararlaştırılmıştır (Lütfi, I, s. 161; Uzunçarşıl1, Kapıkulu Ocakları, I, s. 244-245).

43 Yüksel Çelik, "Serasker”, TDVİA, XXXVI, s. 547-549; Lütfi, Tarih, I, s. 148; Vak'anüvis Esad Efendi Tarihi, Ziya Yılmazer (haz.), (İstanbul: Osmanlı Araştırmaları Vakfı, 2000), s. 628. 
atıl Sultan Sarayları'nın yıkılmasıyla elde edilecek araziye inşası ve humbaracıların süvari sınıfına tahsisi öngörülmüştür. ${ }^{44}$ Ancak daha sonra bu karardan vazgeçilerek Râmî Çiftliği civarında inşasında karar kılınmıştır. ${ }^{45}$ Vakanüvis Esad Efendi herhangi bir nedenden bahsetmiyorsa da Kâğıthane'nin şehir merkezine çok yakın olması, topografyanın geniş talim meydanlarına ve atış talimgâhlarına müsait olmaması gibi hususlar söz konusu karar değişikliğinin muhtemel gerekçeleri olabilir. Öte yandan Râmî Çiftliği civarının rakım itibarıyla yüksek olması, meskûn mahallere daha uzak oluşu ve özellikle Davudpaşa Kışlası ile arasında askeri talimlere elverişli geniş meydanların bulunması bu tercihi etkileyen diğer unsurlar olmalıdır. Keza yeni kışlanın Davudpaşa Sarayı civarında inşasıyla Rumeli Kolu'na yapılacak seferlerde ordunun uğurlandığı mıntıkada adeta bir askeri bölge/site tesis edilmiş olunacaktı. Bu suretle Rumeli'de alınacak mağlubiyetlerin Osmanlı başkenti açısından tehdit yaratması durumunda, söz konusu askeri bölge, İstanbul'un muhafazasında önemli bir direniş ve destek noktası teşkil edecekti.

Başkentin en önemli gündem maddesi yeni ordunun teşkilatlanması ve bunun da en önemli unsurlarından olan yeni kışlaların inşası olduğundan, Seraskerlik makamı tarafından söz konusu kışlaların ahşaptan maketleri hazırlatılmıştır. Bu meyanda Serasker Hüsrev Mehmed Paşa tarafindan maketi/modeli (resm-i mücessem) hazırlatılan Râmî Kışlası'nın Ebniye-i hassa müdürü vd. görevlilerle keşfi yapılmış ve 427.083 kuruşluk muhammen inşaat bedeli çıkarılmıştır. Maliyeti düşürmek amacıyla kışla içine yapılacak camii minaresinin inşasının sonraya bırakılarak maliyetin 417.854 kuruşa çekilmesi yönündeki karar ${ }^{46}$ hazinenin bu esnada hayli zor durumda olduğuna delalet etmektedir.

Yeni kışlaların hangi mevkilerde inşa edileceğinin netleştirilmesinin ardından Haziran 1826 sonlarında (evahir-i Zilkade/26 Haziran-5 Temmuz 1826) daha önce humbaracıbaşılık ve Tophane bina eminliği yapmış olan Kapıcıbaşı Serficeli

44 BOA, Hatt-1 Hümayun (HAT), nr. 595/29200. Bu arada Levent Çiftliği Kışlası'nın da tamiri ve ihyası düşünülmüşse de kereste vb. inşaat malzemelerinin temininde yaşanabilecek sıkıntılar, keza amele tedarikinde karşılaşılması muhtemel zorluklar ve ek maliyetin yüksekliği gibi gerekçeler nedeniyle söz konusu tamirat tehir edilmiştir.

45 Esad, Tarih, s. 628.

46 BOA, C.AS, nr. 471/19646. Belgede kışlanın maliyetinin karşılanacağı gelir kalemlerine dair önemli ayrıntılara da verilmiştir. Ordunun 1828-29 Rus Savaşı nedeniyle cepheye sevki gündeme gelince Râmî Kışlası'ndaki süvariler de gideceğinden yeni bir masrafa yol açmamak amacıyla hem Râmî hem de Davudpaşa kışlalarının minarelerinin inşası bir süre daha ertelenecektir (BOA, HAT, nr. 594/29148). 
Mehmed Ağa Râmî Kışlası'nın, sabık sadrazam Abdullah Paşa hazinedarı Sipahiler Ağası Kapıcıbaşı Mehmed Ağa Davudpaşa Kışlası'nın, Yusuf Agâh Efendi’nin yakını ve sabık Filibe Nazırı Moralı Osman Efendi ise Selimiye Kışlası'nın bina eminliklerine tayin edilmişlerdir. ${ }^{47}$ Mehmed Dâniş Bey, Râmî Çiftliği Kışlası'nın Humbaracıların süvarilerine tahsisi düşünüldüğünden, daha önce Humbarahane nazırlı̆̆ yapmış olan Serficeli Mehmed Ağànın bina emini olarak tercih edildiğinin altını çizmiştir. ${ }^{48}$

Bir buçuk yıllık hummalı bir çalışmayla, inşaat işlerinin mümkün mertebe aksamasına meydan verilmeyerek 1827 sonbaharında Râmî Çiftliği Kışlası'nın ana yapısının üzeri örtülmüş ve çatıya kiremitlerin büyük bir kısmı döşenmiştir. Bina Emini Serficeli Mehmed Ağa bir ay zarfında kışlanın işlerinin tamamlanabileceğini dile getirince, gerekirse kışın dahi inşaatın devamı yönünde karar alınmıştır. ${ }^{49}$ Kışlanın inşaatı tamamlanma aşamasına gelince Haremeyn Müfettişi Şair Keçeci-zâde İzzet Molla'ya kitabesi sipariş edilmiştir. İzzet Molla kaleme aldığ tarihi arz edince, bir başka mesele gündeme gelmiştir. Şöyle ki; kışlanın inşası yönünde karar alındığında buranın Humbarahane’ye bağlı sipahilere tahsisi öngörülmüştü. Padişah kışlaya yerleştirilecek askeri sınıfın netleştirilmesini ve İzzet Molla tarafından kaleme alınacak tarih metninde adı zikredilecek sınıfla ileride buraya yerleştirilecek birliklerin tezat teşkil etmemesine bilhassa dikkat edilmesini irade etmiştir. Bunun üzerine mevcut tarihin "kasidesindeki humbaracı ocağı" ibaresi kaldırılarak tüm birlikleri kapsayacak şekilde "asker" ifadesi öne çıkarılmış ve tashih edilen tarih kitabesi kışla kapısına asılmıştı.. ${ }^{50}$

47 BOA, HAT, nr. 595/29200; Esad, Tarih, s. 628; a. mlf, Üss-i Zafer, (İstanbul: Süleyman Efendi Matbaas1, 1293), s. 193-195; Lütfi, Tarih, I, s. 148; A. Cevad, Târih-i Askerî-i Osmânî, İÜ, TY, nr. 4178, II/IV. kitap, s. 6; Netîcetü'l-Vekāyi‘, s. 71-72. Esad Efendi ayrıca III. Selim devrinde süvari kışlası olarak kullanılan ve o sırada atıl halde bulunan Üsküdar Atik Valide Camii tabhanesinin kışla (me’vâ-yı asker) şeklinde tamiri yönünde karar alındığını ve bina eminliğine de Bilecik Voyvodası Ali Efendi’nin atandığını nakletmiştir (Esad, Tarih, s. 628).

48 Netîcetül-Vekāyi‘, s. 66, 71-72.

49 BOA, HAT, nr. 595/29199.

50 BOA, HAT, nr. 957/41096; HAT, nr. 667/32505; HAT, nr. 310/18332; HAT, nr. $593 / 29050$. 
İzzet Molla tarafından kaleme alınan tarihler şöyledir: ${ }^{51}$

\section{Târîh-i Kışla-i Râmî}

Şâhenşeh-i muzaffer zull-ı zalîl-i Ma bûd

Tertîb kuldı askeri nusretle ola meviud

Ta lìm-i leşker itdi, tanzîm-i kişver itdi

Terkîm-i defter itdi oldı cünûdı mevcûd

Her yerde itdi inşâ bu kışla-i mu'allâ

Kıldı cünûdın ihyâ hâkân-ı kişver-i cûd

Ez-cümle kışla-i nev eflàke saldı pertev

Yanında kaldı bir ev nüh kal'a-i zer-endûd

Hakkâ ki rûşen oldı bir başka gülşen old

'Izzet ararken oldı târîhi bâğ-ı maksûd (1243).

\section{Diğeri:}

Tard itdi hầinânı tathîr idüp cihânı

Kıldı der-i zamânı Yécûc-ı şerre mesdûd

Buldı civâr-ı Hâlid 'askerle hüsn-i zầid

Ashâba ola âid hayr-ı şeh-i cihân-sûd

Oldukda cünd-i nusret gars-ı yemîn-i şevket

Gülzâra döndi devlet hâr-ı gam oldı nâ-bûd

Virdi cihâna revnak ol pâdişeh-i mubakkak

Ahd-i şerîfini Hakk şevketle ide memdûd

Cevherle kilk-i üstâd târîhin itdi ta'dâd

Râmî̀de kıldı îcâd nev kı̧̧la Hân Mahmûd (1243).

51 Keçeci-zâde İzzet Molla, Dîvânçe-i İzzet-i Nâdî̀de-Güftâr be-Nâm-ı Hazân-ı Âsâr, (İstanbul: Takvimhâne-i Âmire, 1257), s. 17. İzzet Molla’nın 1257'de basılan Hazân-ı Assâr adlı divançesinin 12 Ekim 1841'de satışına izin verilmesine dair bkz. BOA, İrade Dâhiliye (İ.DH), nr. 46/2260. 


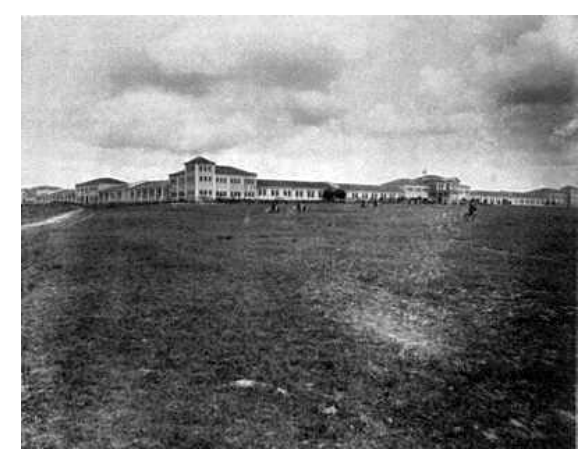

Mubtemelen 1880’li yıllarda Rami Kışlası ve Önündeki Talim Meydanı

Vak'a-i Hayriyye'nin ardından yeni askeri sistemin teşkili kapsamında Humbarahane'ye bağlanan sipahilerin Asâkir-i Mansûre süvarisi olarak istihdamı ve Râmî Kışlası'nın da bunlara tahsisi öngörülmüştü. Ancak bunların statüsünün tam olarak netleşmemiş olması, 1827 yılı itibarıyla Tersane kanunnamesinin hazırlığı nedeniyle yaşanan yoğunluk ve ileride Râmî Kışlası'na kalyoncuların, Mansûre askerinin veya teşkil edilecek yeni süvari birliklerinin yerleştirilme ihtimaline binaen tek bir askeri sınıfa tahsisi kararından vazgeçilmesinin uygun olacağı arz edilmiştir. Buna mukabil padişah, Tersane askerinin sayısının hızla artacağını ve bu sebeple bunlar için yeni kışla yapılmasının şart olduğunu ifade ederek Hasköy'deki humbaracı ve lağımcı kışlasının tersane birliklerine ve Râmî Çiftliği Kışlası'nın da humbaracı ve lağımcı gibi teknik sınıflara tahsisinin uygun olup olmadığının Serasker Paşa ile müzakere edilmesini irade etmiştir. Râmî Kışlası’nın "atlı kışlası” olarak kullanılmasına pek yanaşılmamasında, süvariler için yapılması şart olan ahırların inşası için ilave zamana ihtiyaç olması ve hazineye getireceği ek maliyetten kaçınma düşüncesi de etkili olmuştur. ${ }^{52}$

Sadrazam Benderli Mehmed Selim Sırrı Paşa, padişahın iradesi doğrultusunda Serasker, Humbarahane nazırı ve Kapudan-1 derya ile konuyu müzakere etmiş ve özetle; Humbarahane'nin eskiden beri sahilde bulunduğu; gerek taşradan bu askeri tesise gerekse Humbarahane'den taşraya hammadde ve mamul madde nakli için sahilde bulunmasının şart olduğu, Humbarahane Kışlası bitişiğindeki depolardan çıkarılacak malzeme ve mühimmat için Râmî Çiftliği Kışlası'nda yeni depoların inşasının gerekeceği, bunun ise hem güç hem de masraflı olacağı, ambarlar, Humbarahane nazırı, usta ve subaylarının yerlerinde bırakılması sadece

52 BOA, HAT, nr. 310/18332. 
kışladaki Humbaracı-Lağımcı neferlerin tahliyesiyle yerlerine Kalyoncu askeri konulması halinde Humbarahane ve Dökümhane'deki işleyişin tamamen aksayacağ 1 ve benzeri nedenlerden ötürü Humbaracı ve Lağımcıların Râmî Çiftliği Kışlası'na naklinin imkânsız olduğunu arz etmiştir. Kalyoncuların istihdamı konusuna da temas eden Sadrazam, Tersane Divânhânesi önünde Kum Meydanı'nda Kaptan-ı deryanın hayvanlarına mahsus dört tarafı taş duvarla çevrili büyük ahırda kışla benzeri bir bina bulunduğunu, eklenecek binalarla iki bin askerin burada bar1nabileceğini ve az bir masrafla işin halledilebileceğini ifade etmiştir. Buna karşın Râmî Çiftliği Kışlası'na yerleştirilecek askeri sınıfın henüz belirlenmemiş olması padişahın şu satırları kaleme almasına neden olmuştur: "Bu Râmî Çiftliğìndeki kışlanın ibtidâ-yı emirde inşâsı husûsunda iyice mütâlaa olunmaksızın kararsızca yapılmış olduğundan işte el-ân bir sûret verilemeyerek öylece kaldı." Biran önce bu sorunun çözümlenmesini isteyen II. Mahmud aksi halde "bu kışla askersizce kalacak" şeklinde yetkilileri ikaz etmiştir. ${ }^{53}$

Râmî Kışlası'nın mimarının kimliği konusu henüz netlik kazanmamıştır; Bu belirsizlikte XIX. yüzyıl mimarlık teşkilatının işleyişi ve idari reformlar esnasında bu alandaki değişim ve dönüşümün boyutlarının henüz tam olarak ortaya konulmamış olması başlıca etkenler olarak öne çıkmaktadır. Bu sorun mimarlık tarihçilerinin arşiv kayıtlarına dayanan çalışmalarıyla ve tarihçilerin de mimarlık tarihçilerine yapacakları katkılarla aşılabilecektir. Mevcut literatürde tekrarlana gelen bilgi 1827-28'de II. Mahmud tarafından kışlanın Kirkor Amira Balyan’a (Kirkor Kalfa) yaptırıldığı yönündedir. ${ }^{54}$ Buna mukabil Kirkor Kalfa’nın mimar değil Balyan ailesinin bir ferdi olarak binanın müteahhidi olduğu, mimarının ise Ebniye-i Hassa Müdürü Abdülhalim Efendi olduğu öne sürülmüştür. ${ }^{55}$ Vakıa Râmî Çiftliği Kışlası'yla ilgili belgelerde; gerek plan-proje, gerek keşif ve gerekse inşaat sürecinde Ebniye-i Hassa Müdürü Abdülhalim Efendi daima ön plandadır; inşaata başlandığında ve daha sonraki kapsamlı tamirat dönemlerinde, kışlanın

53 BOA, HAT, nr. 593/29050.

54 Pars Tuğlacı, Osmanlı Mimarlı̆̆ında Batılılaşma Dönemi, s. 10, 35; Doğdu, "Kışlalar", Türkler, XII, s. 181.

55 Selman Can, "Osmanlı Mimarlık Teşkilatının XIX. Yüzyıldaki Değişim Süreci ve Eserleri ile Mimar Seyyid Abdülhalim Efendi”, (doktora tezi, İstanbul Üniversitesi, 2002), s. 63-64 vd; a.mlf, Bilinmeyen Aktörleri ve Olayları ile Son Dönem Osmanl Mimarlı̆̆ı, (İstanbul: Erzurum İl Kültür ve Turizm Müdürlüğü Yay., 2010), s. 103; a. mlf, "XIX. Yüzyılda Osmanlı Mimarlığının Teşkilat Yapısı ve Balyanlar", 150. Yılında Dolmabahçe Sarayı Uluslararası Sempozyumu (23-2 Kasım 2006), Kemal Kahraman (ed.), (İstanbul: TBMM Milli Saraylar Daire Başkanlığı, 2007), I, s. 72. 
planları yanında ahşaptan maketleri (resm-i mücessemi) bizzat kendisi tarafından padişaha sunulmuş ve beğenilen bu maketler bina eminlerine gönderilerek söz konusu kışlanın o şekilde inşası yönünde talimat verilmiştir. ${ }^{56}$ Abdülhalim Efendi döneminde yapımına başlanan kışla, Kırımlı Mahmud Ağa’nın başmimar olduğu dönemde tamamlanmıştır. ${ }^{57}$

1828 sonbaharında kışlanın inşası tamamlanma aşamasına geldikten sonra bu defa padişahın teklifi ile yanına bir hastane, değirmen, fırın ve ambarlar yapılması, böylece bir kışla kompleksine dönüştürülmesi gündeme gelmiştir. Bu sadece Râmî Kışlası için değil, merkezde ve taşrada inşası tamamlanan ya da süren diğer kışlalar için de geçerliydi. Fizibilite çalışmalarının ardından ilgası gündemde olan Bostancı ocağının tahliye edeceği Davudpaşa Sarayı'nın alt tarafındaki binaya yapılacak ilavelerle Davudpaşa Kışlası'nın hastane ihtiyacının karşılanacağı, Selimiye Kışlası'nın zaten hastanesinin bulunduğu arz edilmiş, hastanesi olmayan ve yakınında bu ihtiyacı karşılayacak uygun binası da bulunmayan yegâne kışlanın Râmî Kışlası olduğunun altı çizilmiştir. Buna mukabil Sultan II. Mahmud Bostancıların tahliye edeceği ahşap binaların bir takım eklemelerle hastaneye dönüştürülmesinin az masrafla gerçekleşebileceğini, ancak kâgir olmadığından kısa sürede yıpranacağı için astarın yüzünden pahalıya mal olacağını ifade etmiştir. Bu nedenle Padişahın teklifi: Davudpaşa ile Râmî kışlaları arasındaki mesafe fazla olmadığından iki ayrı hastane binası inşa edilmektense iki kışlanın askerlerinin birbirine karışmasına meydan verilmeden; iki cepheli, giriş ve çıkışları ayrı ve sırt sırta vermiş kâgir bir hastanenin söz konusu iki kışlaya eşit uzaklıkta bir mevkide inşası ve bunun çok daha makul ve düşük maliyetli olacağı yönündeydi. ${ }^{58} \mathrm{Her}$ bir cenahı 500 hasta kapasiteli olarak yapımı öngörülen ortak hastane binasının maketi yine Ebniye-i Hassa Müdürü Abdülhalim Efendi tarafından hazırlanmıştır. Serasker Hüsrev Mehmed Paşa ile Hekimbaşı Behçet Molla maketi ve planları inceledikten sonra bazı eksiklikler tespit etmiş, ardından bu ikili Abdülhalim Efendi'yle birlikte inşaat alanına giderek sahada gerekli incelemeleri yapmış ve önerilerini sıralamışlardır. Bu görüşmede, Râmî Kışlası'na henüz ne kadar asker yerleştirileceğinin belli olmamasından ötürü hastanenin sadece Davudpaşa Kışlası'na hizmet verecek kısmının inşası gündeme gelmişse de ortak temelin atılmış olması ve her halükârda Râmî Kışlası için de hastane inşasının şart olduğu ve

56 BOA, HAT, nr. 29041-B; 29041-C; HAT, nr. 29153.

57 BOA, D.BŞM.BNE, nr. 16351.

58 BOA, HAT, nr. 597/29296. 
ertelemenin ileride daha fazla mali külfet anlamına geleceği vb. gerekçelerle iki cenahın inşasının birlikte yürütülmesinde karar kılınmıştır. ${ }^{59}$

Yukarıda işaret edildiği üzere Râmî Kışlası'na hangi birliklerin yerleştirileceği uzun süre muallakta kalmıştı. Sonuçta Çankırı (Kangırı), Kütahya ve sair taşra vilayetlerinden İstanbul'a gelen "tımarlı sipahi süvarileri” Haziran 1828'de Davudpaşa ve Râmî kışlalarına yerleştirilmişlerdir. ${ }^{60}$ Kısa süre sonra 1828-29 Osmanlı Rus Savaşı'nın patlak vermesi üzerine padişah Enderun süvarilerini alarak 25 Eylül 1828'de Râmî Çiftliği Kışlası'na yerleşmiş ve bu suretle kışla fiilen süvari kışlasına (atlı kışlası) dönüşmüştür. ${ }^{61}$

Rami Çiftliği Kışlası, ortası açık avlulu kareye yakın dikdörtgen planlı bir askeri kompleks olarak inşa edilmiştir. Kışla yapıları; hünkâr kasrı, koğuşlar, zabit daireleri, camii, hamam, mutfaklar, tuvaletler (memşâ), ahırlar, sundurmalar, fırın, çamaşırhane, su terazileri, kasr-1 hümayunun iki yanında ve yangına hızla müdahale veya kuraklık durumunda su tedariki için inşa edilmiş olan iki havuz, depolar (mağazalar) ve cephaneliklerden oluşmaktaydı. Ayrıca kışla içinde neferlerin ciddi olmayan sağılı sorunlarını tedavi amacıyla teşkil edilmiş bir de revir mevcuttu. Kışlanın önemli unsurlarından biri de 1834'te başlatılan inşaat-tamirat sürecinde camiin iki yanına müstakil iki yapı olarak ilave olunan Mekteb-i Fünûn-1 Harbiye idi. ${ }^{62}$

Kışlanın özgün planı, orta avluya bakan bir koridora açılan mekânlardan oluşmaktaydı. Dikdörtgen şeklinde ve ortası avlulu olarak inşa edilen yapı $325 \times 390$ m, orta avlu ise 270x337 m boyutlarındadır. Kışlanın kanatları (koğuşların yer aldığı kısımlar) tek katlı, köşe bölümleri (zabit daireleri) ise iki katlıdır. ${ }^{63}$ Yapının güneydoğu kanadı aksında dışarı taşırılmış bir giriş bölümü ve diğer kanatlarının aksında orta avluya açılan birer girişi vardır. Kanatların köşe bölümleri dışa doğru çıkıntılı yapılmıştı.

59 BOA, HAT, nr. 593/29058. Belgede inşasına başlanan hastanenin planında görülen eksiklikler ve maliyeti ile ilgili ayrıntılar yer almaktadır.

60 BOA, C. AS, nr. 527/22007. Süvarilere verilen tayinata dair ilmühaberin başlangıç tarihi 1 Z 1243 olduğuna göre söz konusu birlikler 14 Haziran 1828'de kışlaya yerleştirilmiş olmalıdir.

61 Hafız Hızır İlyas Efendi, Vekāyi ${ }^{\prime}-i$ Letâif-i Enderûniyye, (İstanbul: Dârü’t-Tıbaatü'lAmire, 1276), s. 440-441; Târih-i Livâ, s. 3-6.

62 BOA, C. AS, nr. 12543; C. AS, nr. 19172; Y.PRK.ASK, nr.37/62; C.SH, nr.18/899.

63 Doğan Kuban, Osmanlı Mimarisi, (İstanbul: YEM Yayınları, 2007) s. 556'da yapının iki katlı olduğunu ifade ederse de bu doğru değildir. 
Dört kapısı bulunan kışla yapılarının cepheleri neoklasik üslupta ve yapı aksında yer alan girişlere göre simetrik düzendeydi. Güneydoğu kanadındaki giriş kapısı basık kemerli, güneybatı kanadındaki giriş kapısı ise yarım daire kemerli olup iki yanında pilastrlar ve üçgen alınlıklı bir çatıyla vurgulanmıştı. Kışlanın güneybatı ve kuzeybatı kanatlarında pencereler düz atkılı ve yarı daire kemerli olup söveyle çevriliydi. Mermer kaplı kapının üstüne kitabe ve bitkisel bezemelerle çevrili oval tuğra madalyonu yerleştirilmişti. Ancak tuğralar ve kitabeler 28 Mayıs 1927 tarih ve 1057 sayıl1 "Türkiye Cumburiyeti Dâhilinde Bulunan bi'lcümle Mebânî-i Resmiyye ve Milliye Üzerindeki Tuğra ve Methiyelerin Kaldırılmasi” kanunu gereği kazınmış ve kaldırılmıştır.

Yapım tekniği itibarıyla yığma kâgir olarak inşa edilen kışlanın beden duvarları $1 \mathrm{~m}$. kalınlığındadır. Yapının taş ve tuğla malzemeden yapılmış almaşık örgüdeki güneybatı kanadında payandalar mevcuttur. Kışlanın özgün kat döşemeleri ahşap, kirişlemeli koridorları ise tonoz örtülüdür. Tonozlar taş ve tuğladan mamul girift bir malzemeden yapılmıştır. Bina iç koridoru her $80 \mathrm{~m}$.'de bir kemerle desteklenmiştir. Yapının güney köşesinde ve güneybatı kanadının dış cephelerinde metal kılıçlar vardır. Orta avlunun güneydoğu yönündeki bağımsız birimin 82 cm kalınlığındaki beden duvarlarında 10x22x6 cm boyutlarında ve 1328 (190910) tarihli damgalı dolu tuğlalar kullanıldığ

\section{Râmî Kışlası'nın İdari ve Askeri Bir Üs Haline Gelmesi}

Yaklaşık $220.000 \mathrm{~m}^{2}$ arazisiyle Selimiye ve Davudpaşa'dan sonra İstanbul'un üçüncü büyük kışlası olan Râmî Kışlası'nın askeri ve idari bir üs haline gelmesi, 1828-29 Osmanl1-Rus Harbi nedeniyle Sultan II. Mahmud'un maiyeti ve Enderun süvarileriyle kışlaya yerleşmesi ve yaklaşık iki yıl süreyle devlet idaresini buradan yürütmesinin tabii bir neticesidir. 1828 ilkbaharında Rus ordusu Prut nehrini geçerek savaşı başlatınca 20 Mayıs 1828'de Bâbıâli'deki umumi meşveretin ardından savaş kararı alınmıştı. Rumeli cephesine Tuna seraskeri unvanıyla Ağa Hüseyin Paşa, Varna muhafızlığına Kaptan-1 derya Darendeli İzzet Mehmed Paşa ve Anadolu cephesine eski sadrazamlardan Mehmed Said Galib Paşa atanarak savunma tertibatı alınmış, akabinde 24 Mayısta Davudpaşa sahrasından Rumeli'ye

64 Aynur Çiftçi, “19. yüzyılda Osmanlı Devleti’nde Askeri Mimari ve İstanbul'da İnşa Edilen Askeri Yapılar”, I-II, (doktora tezi, Yıldız Teknik Üniversitesi, İstanbul, 2004), I, s. 96-97; İlgi Yüce Aşkun-Haluk Sezgin, "Râmi Kışlası Hakkında", Tasarım Dergisi, 5/48, s. 85-86. 
ilk Mansure birlikleri sevk edilmişti. Patlak veren bu savaşta yeni ordunun henüz teşekkül safhasında olmasının yarattı̆̆ı sorunlar bir yana, Navarin Faciası'ndan (20 Ekim 1827) dolayı donanmadan mahrum kalan Osmanlı Devleti açısından çok ciddi bir engeldi. Bu durumu iyi değerlendiren Rusya kısa sürede Kalas, Tolçi, Maçin, İsakçı ve İbrail kalelerini ele geçirmiş ve Varna’yı kuşatmıştır. ${ }^{65}$

Rus Harbi nedeniyle 15 Temmuz 1828'de Sadrazam Selim Mehmed Paşa serdar-1 ekrem unvanıyla sefere çıkmıştır. Cepheye sevk edilen orduyu ve ahaliyi teşvik etmek amacıyla II. Mahmud 12 Eylül 1878'de Beylerbeyi'nde yapılan Cuma Selamlığı'nda bizzat sefere çıkacağını ve bu amaçla Sancak-1 Şerif'le surdışında bulunan Râmî Çiftliği Kışlası'na hareket edeceğini ilan etmiştir. ${ }^{66}$ Sefer hazırlıkları tamamlandıktan sonra 13 Eylülde Beşiktaş Sarayı'ndan Topkapı Sarayı'na geçen padişah 15 Eylül 1828 günü eşref saatte Hırka-i Saadet Odası'ndan Sancak-1 Şerif'i alarak süvari Enderun ağalarıyla birlikte gösterişli ${ }^{67}$ bir alayla Dîvânyolu üzerinden Râmî Kışlası'na hareket etmiştir. Râmî̀ye ulaşıldıktan sonra ilk iş olarak kışlanın dört kulesinden üçüne kırmızı, Sancak-1 Şerif'in dikileceği kuleye ise yeşil canfesli sancak dikilerek diğerlerinden ayrılmıştır. ${ }^{68}$ Davudpaşa Kışlası’na bakan kuleye dikilen Sancak-1 Şerif'in şeyhliğine Enderun'dan çırak edilmiş olan Şeyh Şakir Efendi atanmış ve sancak kulesinin yanında hususi bir oda tahsis edilerek zafer için dua ve zikirle meşgul olması emredilmiştir. ${ }^{69}$

Sancak-1 Şerif dikildikten sonra II. Mahmud kışlanın ortasındaki taht kapısının (büyük kapı) üstünde bulunan Daire-i hümayuna yerleşmiştir. Eyüp istikametindeki kule silahtar ağaya, Sancak-1 Şerif hizasındaki kule Asakir-i Hassa Nazırı Said Efendi'ye ve diğer kule ise Matbah Emini Tahir Efendi'nin ikametine tahsis edilmiştir. Enderun ağalarından oluşan iki bölük süvari ve sayıları 60-70 kadar olan mızıkacılar padişahın kaldığı mekânın sağındaki ve solundaki odalara, neferler ise kışla etrafındaki tabya ve metrisler civarında kurulan çadırlara

65 Lütfi, Tarih, I, s. 291 vd.; Netayicül-Vukûat, III-IV, s. 257; Enver Ziya Karal, Osmanlı Tarihi, (Ankara: Türk Tarih Kurumu,1988), V, s. 118-122; Mufassal Osmanl Tarihi, V, s. 2901-2916.

66 Hizır İlyas Efendi, Letâif-i Enderûn, s. 439.

67 Adolphus Slade bizzat kendi müşahedelerine dayanarak bu gösterişli alay hakkında ilginç ayrıntılar vermektedir (Slade, Türkiye Seyahatnamesi, s. 85).

68 Târih-i Livâ, s. 3-7. Sancak-1 Şerif Şeyhülislam Yasinci-zâde Abdülvehhab Efendi, Kaymakam Ahmed Hulusi Paşa ve Serasker Hüsrev Mehmed Paşa tarafindan dualar eşliğinde kuleye dikilmiştir.

69 Letâif-i Enderûn, s. 440-442. 
yerleştirilmişler, ${ }^{70}$ hazariyetin seferiyete tebdilinin göstergesi olarak ayrıca padişah için de bir Otağ-1 hümayun kurulmuştur. Daha sonra Rumeli cephesinden gelen haberler ve bunlara istinaden alınacak önlemler, ileri gelen devlet adamları ile zaman zaman burada müzakere edilmiş ve karara bağlanmıştır. ${ }^{71} \mathrm{Bu}$ arada Saray'dan padişahla birlikte ayrılan haremi, Eyüp Defterdar İskelesi'nde bulunan Beyhan (Peykhan) Sultan Sarayı' na yerleştirilmiştir. ${ }^{72}$

Kışladaki zikir halkaları ve tevhîd cemiyetleri, akşam namazlarından sonra Sancak-1 Şerif Şeyhi Şakir Efendi reisliğinde Enderun ağaları ve bizzat padişahın katılımıyla neredeyse aksatılmadan sürdürülmüştür. Yine padişah Eyüp Camii'nde yapılan Cuma selamlıklarının ardından Halid b. Zeyd'in (Ebâ Eyyûb el-Ensârî) türbesinde Kur'an okuyarak ve Fatih Sultan Mehmed'in kullandığı seccadede namaz kıldıktan sonra ceddinin ruhaniyetinden istimdat ile ordunun muzafferiyeti için dua ederek bu manevi atmosferi daha da pekiştirmiştir. ${ }^{73} \mathrm{Ordu}-$ nun muzafferiyeti için esbâb-ı zâhire ve bâtınaya mürâcaat olarak ifade edilen bu tür faaliyetlerin bir iltica ve tevekkül halinin ötesinde başka gerekçeleri de vardı. Osmanlı idari-askeri geleneğinde yeri olan bu tür uygulamaların, aynı zamanda Sultan II. Mahmud açısından teşebbüs ettiği bir takım ıslahatların muhafazakâr çevrelerde yarattığı olumsuz havayı dağıtmak için iyi bir fırsat ve etkili bir propaganda aracı olduğunda kuşku yoktur.

Mülki ve idari alandaki reformların alt yapısını hazırlamakta olan II. Mahmud askeri ıslahatların teşekkül safhasında hazırlıksız yakalandığı Rusya savaşında ordunun ve halkın motivasyonunu zirveye taşımak amacıyla yüz yirmi beş yıl sonra bizzat sefere çıkmak üzere Topkapı Sarayı'ndan Râmi Kışlası'na taşınmıştır. Osmanlı tarihinde bir ilk olarak, Saray'dan kışlaya taşınmanın arkasında sadece orduyu ve halkı savaşa teşvik etmenin bulunduğunu söylemek güç, en azından eksik bir değerlendirmedir. Şöyle ki; 1828 yılı itibarıyla yeniçeri bakiyesi ya da yeniçerilik zihniyetini paravan olarak kullanan çevrelerin tam anlamıyla tehdit olmaktan çıktığını söylemek mümkün değildir. Zira Vak’a-i Hayriyye'den sonra genelkurmay karargâhı olan Bâbıseraskerînnin yakılması ve komutanlara suikast

70 Târih-i Livâ, s. 6-7. Abdülhak Molla kendisi dâhil diğer saray görevlilerinin nerelere yerleştirildiklerini de ayrıntıları ile nakletmektedir.

71 Târih-i Livâ, s. 13.

72 ayni eser, s. 75.

$73 \mathrm{Bu}$ tür uygulamalar, zikir halkaları ve tevhid cemiyetleri için bkz. Letâif-i Enderûn, s. 442, 451; Târih-i Livâ, s. 7 vd. 
girişimine dek varan bu tehdit, ${ }^{74}$ Rus harbi nedeniyle Mansûre birliklerinin cepheye sevki ve bu sebeple merkezdeki asker sayısının azalmasıyla daha da artmıştı.

Kendisinin de yaralı olarak kurtulduğu saray darbesi ve karşı darbeler esnasında, bir isyan patlak verdiğinde padişahın ne denli korumasız ve çaresiz kaldığını bizzat müşahede eden II. Mahmud, hem muhalif koalisyonun isyan çıkarma endişesinden hem de peyderpey tatbikat sahasına koymak istediği sosyal ve idari reformların muhafazakâr-statükocu çevrelerde yaratacağı tepkiden çekinmekteydi. Şüphesiz padişahın Topkapı Sarayı'ndan Râmî Kışlası'na taşınması ve orada iki yıl kadar ikameti ihtiyar etmesinde, cephedeki birlikleri teşvik etmek maksadı da önemli bir husustu. Ancak bunu, selefleri gibi Saray'dan yapmasına mani bir durum olmadı̆̆ı da açıktır. O halde beş çeyrek asır öncesinde kalmış bir uygulama olarak, bizzat sefere çıkacağını ilan etmesinin ardında başka sâikler olmalıdır. Daha önce de işaret edildiği üzere, cephedeki ordunun teşviki ve başkent halkına seferberlik psikoloji aşılanması açısından kışlaya taşınma elbette ki sembolik bir anlam taşımaktaydı. Ancak zamanla bu sembolik adımın yani padişahın bizzat sefere çıkma kararının fiilen askıya alınması ve savaş sürecince Saray'da değil de kışlada ikamet suretiyle meşakkat ve zahmet noktasında kader birliği yapıldığ1 izlenimi vermeye dönüşmesinin nedeni/nedenleri ne olabilir? Kanaatimizce II. Mahmud, patlak veren 1828-29 Osmanlı-Rus Savaşı'nın ardından Enderun ağalarından oluşturduğu talimli süvari birlikleriyle (bu birliği hizmetkârlarından oluşturulan bir muhafız alayı gibi değerlendirmek de mümkündür) Râmî Kışlası'na yerleşmekle kendisini güvenceye almak istemiş, muhtemel bir isyanda Kapıkullarının kapıyı bırakıp Saray’a yürüdüklerinde, kaderine razı olmak seçeneğine boyun eğmemiştir.

Avusturya Başvekili Metternich'in talimatıyla Mart-Nisan 1830'da Osmanlı başkentindeki gelişmeleri rapor etme misyonuyla gönderilen Albay Comte

74 Ocağı ihya etmek amacıyla işi suikasta kadar vardıran ve daha sonra yakalanan elebaşıların ifadeleri için bkz. Uzunçarşılı, Kapukulu Ocakları, I, 576-595; Esad, Tarih, s. 774-775; Ahmed Cevdet Paşa, Târih-i Cevdet, (Dersaadet: Matbaa-i Osmaniye, 1309), XII, s. 188; A. Cevad, Târîh-i Askerî-i Osmânî, İÜ. TY, nr. 4178, II/IV, 16; Lütfi, Târîh, I, 159-60. Askeri reformlara muhalif olanların taşradaki faaliyetlerine dair bkz. Lütfi, Târih, I, 173 vd; Hamiyet Sezer, "Yeniçeri Ocağının Kaldırılışının Taşradaki Yansıması (1826-1827)", AÜDTCF Tarih Araştırmaları Dergisi, XXX, (1998), s. 215237; Ahmet Cevat Eren, Mahmud II. Zamanında Bosna-Hersek, (İstanbul: Nurgök Matbaas1, 1965). Goodwin bu dönemde İzzet Mehmed ve Hüsrev Mehmed paşaların emirleri doğrultusunda binden fazla yeniçerinin boğdurulduğunu öne sürer (Goodwin, Yeniçeriler, s. 247). 
Malaguzzeny, kaleme aldığı mufassal raporunda tespitimizi doğrulayacak şu satırlara yer vermiştir:

Sultanin Râmî Kı̧̧lasinda ikamet etmesinin sebebi, çok sevdiği askerlerinin arasinda bulunmak ve Istanbul'da mevcut olan bir ihtilal korkusudur. Zira son hadiselerden sonra Türklere (sıradan insanlar) karşı son derece kuşkucu ve güvensiz olmuştu... Buna istinaden Mabeyinci Mustafa Efendi şunları söyledi: Bu ayak takımı bir ihtilal yapacaktr, bizim ise engel olacak yeterli gücümüz yok, neyse ki şimdilik Sultan'in korkusundan dolayı bir şey yapamıyorlar. ...Sultan II. Mahmud, Serasker Hüsrev Paşa’nın kışkırtmaların engelleyecek vasıtalardan mahrumdu, başkentteki gelişsmeleri yakından takip ediyordu ve açık bir isyandan korkuyordu ... Mâbeynci Mustafa Efendi İstanbul'da dolaşan casusların parasın kendi cebinden verir, böylece kahvehaneler ve pazarlarda hükümet ve Sultan'la ilgili konuşmaları ögrenir, bazen bizzat kendi de gider dolaşır. Birçok görevli bir gün önce olup bitenleri haber vermek için, hemen her sabah gelir ve ona rapor verir. ${ }^{75}$

Albay Comte Malaguzzeny'nin de belirttiği gibi İstanbul'da emniyet ve asayişin sağlanması, gerek reformlar ve gerekse mevcut savaş nedeniyle "devlet sohbeti" yaparak yönetimi tenkit edenlerin tespiti için casusların sayısı arttırılmıştır. Öte yandan rutin hadiseler yanında, özellikle Rumeli cephesinde meydana gelen gelişmeler, sadaret kaymakamı tarafından vakit geçirilmeksizin bazen bizzat bazen de bilvasıta kışlada Sultan'a arz edilmekteydi. Bu dönemde askeri ve idari alanda nüfuzu zirvede olan Serasker Hüsrev Mehmed Paşa da neredeyse her gün Râmi Çiftliği Kışlası'na giderek Sultan'ın huzuruna çıkmakta askeri alandaki gelişmelere dair bilgileri arz etmekteydi. Keza başta silahtar ağa olmak üzere sair saray ve Enderûn ricali ile şehrin güvenliğinden sorumlu diğer görevliler, hatta casuslar da Topkapı Sarayı ve kendi kurumları ile Râmi Kışlası arasında adeta mekik dokumaktaydılar. ${ }^{76}$ II. Mahmud'un Topkapı Sarayı'ndan ayrilıp maiyeti ve bir kısım saray erkânıyla birlikte Râmî Kışlası'na yerleşmesiyle, doğal olarak kışla aynı zamanda idari bir üs niteliği kazanmıştır. İstanbul'da bulunan yabancı elçilerin sadrazamla görüşmek için Râmi Kışlası'ndaki trafiği dikkatle takip ettikleri ve

75 Colonel Comte Malaguzzeny'nin Metternich'e sunduğu Fransızca rapor: Avusturya Devlet Arşivi (Österreichisches Staatsarchiv, Wien), Türkei, HHSa, nr. VI/17, s. 4, 9-10, 17-18, 28. Bu rapordan haberdar edip temin etmemi sağlayan değerli dostum Doç. Dr. Gültekin Yıldız’a ve el yazısının okunmasında yardımlarını esirgemeyen Sayın Sinan Kuneralp'a teşekkür ederim.

76 Colonel Comte Malaguzzeny'nin Prens Metternich'e sunduğu rapor, Avusturya Devlet Arşivi (Österreichisches Staatsarchiv, Wien), Türkei, HHSa, nr. VI/17, s. 11, 13, 16, 28-29. 
sadrazamın sık sık kışlaya uğraması nedeniyle görüşme günlerini ona göre ayarlamaya çalıştıkları görülmektedir. ${ }^{77}$

Râmî Kışlası'na Rumeli'ye sefer niyeti ile yerleşmiş olan II. Mahmud, maiyeti ve Enderun süvarilerine her an sefere çıkacak şekilde hazırlıklı bulunmaları talimatı vermiştir. Öte yandan devlet adamları hala söz konusu savaşın zamanlamasını/gerekli olup olmadığını tartışmaktaydı. Muhalif cenahın sözcülüğ̈̈ne soyunan Haremeyn Müfettişi Şair Keçeci-zâde İzzet Molla, kitabesini de kaleme aldığı Râmî Kışlası'na giderek padişaha arz edilmek üzere layihasını mabeyincilere takdim etmiştir. Ancak bu girişim; gösterişli alaylar, tevhid cemiyetleri ve her şeyden önemlisi saraydan kışlaya taşınmak (hazariyyeti bedeviyyete tebdil etmek) suretiyle cephedeki askere moral vermeye ve başkent ahalisine seferberlik psikolojisi aşılamaya çalışan II. Mahmud'u fazlasıyla rahatsız etmiştir. Daha önce Reisülküttab Pertev Efendi'nin başını çektiği savaş taraftarlarına destek vermek suretiyle tavrını net bir şekilde ortaya koyan padişah, İzzet Molla’nın derhal Sivas’a sürgün edilmesini irade ederek, bu konudaki tavizsiz tutumunu ortaya koymuş ve bu yönde gelecek diğer teklif ve itirazların da önünü kesmiştir. ${ }^{78}$

Askeri reformlardan elde edilecek başarılı sonuçların, diğer alanlarda atılacak sslahat adımlarının referansı ve lokomotifi olacağının pekâlâ farkında olan II. Mahmud, gerek Râmi Kışlası'ndaki talimlerde gerekse kışla dışındaki merasimlerde askeri disipline ve yeni ordunun ihtişamına büyük önem atfetmiştir. Bu cümleden olarak 19 Eylül 1828'de Eyüp Camii'nde yapılan Cuma selamlığında askerlerin gösterişli olmasına çok özen gösterilmiş iç hazineden çıkarılan mercan işlemeli tüfekler ve gösterişli üniformalarla bu ihtişam pekiştirilmiştir. ${ }^{79}$ Benzer şekilde 22 Eylül 1828 'in Mevlid Kandili olmasından istifade ile vüzera ve ulema gösterişli sefer kıyafetleri içinde ve tam teçhizatlı vaziyette padişahın da katılımıyla Mevlîd-i Şerîf okunmuş ve gösterişli bir askeri resmigeçit icra edilmiştir. ${ }^{80}$

Sultan II. Mahmud Râmî Kışlası'na giderken Enderun ağalarından yalnızca süvari sınıfını yanına almıştı. Genelde Yüzbaşı Tebdilci Ahmed Ağa ve yine Yüzbaşı Şerif Ağa bölükleri ile sık sık Davudpaşa sahrasında süvari talimleri yapılmıştır. ${ }^{81} \mathrm{Bu}$ suretle hem kışladaki askeri birlikler hem de halk nazarında Padişahın

77 BOA, HAT, 1206/47286.

78 Lütfi, Tarih, I, s. 293, II, s. 142; Letâif-i Enderûn, s. 448; Târih-i Livâ, s. 23-24.

79 Hizır İlyas Efendi Letâif-i Enderûn, s. 441.

80 Lütfi, Tarih, II, s. 38.

81 Hızır İlyas Efendi, Letâif-i Enderûn, s. 446. 
sefere her an çıkacağı beklentisi canlı tutulmaya çalışılmıştır. Süvari talimlerinin Râmî Kışlası avlusunda değil de Davudpaşa sahasında yapılması, Râmî Kışlası'nın talim alanının yetersizliğinden kaynaklanmaktaydı. Bu dönemde sefer hazırlıklarının bir diğer parçası, Padişahın Baruthane ve benzeri askeri kurumları sık sık teftiş etmesiydi.

Askeri manevralar ve teftişler dışında 1828 sonbaharında Padişahın bir diğer alışkanlığı; Küçükçekmece, Büyükçekmece, Silivri ve Tekirdağ civarına yaptığı av gezileridir. ${ }^{82}$ Avlanma ve askeri manevralarla geçen 1828 sonbaharıyla önce yağmurların yarattığı çamur, ${ }^{83}$ ardından da kış mevsiminin girmesiyle Râmî Kışlası'nın civarındaki çadır ordugâhta barınan askerler kışla içine alınmışlardır. Aşırı şiddetli soğuklarda Padişah Eyüp'te Esma Sultan Sarayı'na, maiyeti ise civardaki konaklara yerleştirilmişlerdir. ${ }^{84}$

1829 ilkbaharında Rus cephesinden zafer haberleri geleceği yönündeki ümidini koruyan II. Mahmud, sık sık maiyeti ve süvarilerle ava çımakta veya savaş manevraları yapmaktaydı. Râmî Kışlası'ndan hareket eden birlikler bazen Silahtar ağanın Ayazağa Çiftliği’ne gitmekte, bazen de Büyükçekmece veya Küçükçekmece civarında avlandıktan ve kurulan otağlarda bir takım müsabakalar tertibiyle eğlendikten sonra yine kışlaya dönmekteydiler. ${ }^{85}$ Padişahın artık bizzat sefere çıkmayacağının kesinlik kazandığı bu dönemde, ilk başlarda sergilenen seferberlik vaziyeti ve psikolojisi, yerini rutin manevralara, tevekkül ve teslimiyet haline bırakmışı. Padişahın maiyetinde bulunan Enderun ağalarından Hızır İlyas Ağa’nın naklettiğine göre; kışla camiinde Ömer Efendi mukarrirliğinde yapılan huzur dersleri, av partileri, biniş gezileri ve bu esnada tertiplenen eğlenceler, kışlada bayramlaşmalar hep bu rutin ve normalleşme halinin tezahürleridir. ${ }^{86} \mathrm{Bu}$ esnada Cerrah Osman Efendi'nin rüyasına giren ve zafer müjdesi veren Merkez Efendi ve Mansûre piyade çavuşuna görünen nurânî bir zatın telkin ve muştuları

82 Târih-i Livâ, s. 37-38, 47-48; Letâif-i Enderûn, s. 452-453.

83 Târih-i Livâ, s. 15.

84 Lütfi, Tarih, II, s. 57-58.

85 Târih-i Livâ, s. 39.

86 Hızır İlyas Efendi, Letâif-i Enderûn, s. 457-460; Târih-i Livâ, s. 44-45, 58-59. Kardeşi Hızır İlyas Efendi gibi bu esnada kışlada bulunan Abdülhak Molla, helva cemiyetleri tertip ile adeta bu moral gecelerinin vazgeçilmez unsurları olarak; hayal (gölge oyunu), saz, meddah ve kuklabazların kışlaya getirtilip sabaha dek süren eğlenceler tertip edildiğini ifade ediyor. Kışlada bu tür eğlenceler daha sonra da tertiplenmiştir (Tarih-i Liva, s. 111). 
da beklenen zaferi getirmeye yetmemiştir. Ancak II. Mahmud'un derhal Merkez Efendi'nin türbesini ziyaret ettiğine bakılırsa ${ }^{87}$ bu tür şeyleri ciddiye aldığ 1 veya popülist davrandığı söylenebilir.

Kışlada vaziyet bu minvalde iken, kuşatma altında bulunan Varna’nın 21 Ekim 1828'de düşmesinin ardından, Rus keşif kolları Karadeniz Boğazı civarında boy göstermeye başlamışlardı. Bu durum başkent ahalisinde büyük endişe yaratınca bir türlü sefere çıkamayan II. Mahmud, oluşan umumi heyecanı teskin etmek ve dedikoduları bertaraf etmek amacıyla Râmî Kışlası’ndan Tarabya'ya geçme kararı almıştır. Gerekçeleri Karadeniz civarının muhafazası ve düşmanı bu bölgede karşılamak olan bu karargâh değişikliği, geniş katılımlı bir merasimle 12 Mayıs 1829'da gerçekleştirilmiş ve Sancak-1 Şerif kışladan alınarak Kalender Kasrı'na dikilmiştir. Bölgede askeri yapılar bulunmadığından padişah ve üst düzey memurlar Tarabyaddaki yalılara, askerler ise çadırlar kurarak Büyükdere istikametindeki sahil şeridine konuşlanmışlardır. ${ }^{88}$ Padişah ve maiyeti Tarabyàya yerleştikten sonra bölgedeki teftişlere ağırlık verilmiştir. $\mathrm{Bu}$ çerçevede II. Mahmud kayıkla Boğaz dışındaki Telli Tabya ve civarındaki kaleleri sık sık teftiş etmiş, bölgeden sorumlu olan Boğaz Nazırı Hamid Ağa’yı teyakkuz halinde olması hususunda uyarmıştır. ${ }^{89} \mathrm{Bu}$ arada padişahla birlikte Tarabyàya götürülmeyen Enderun ağaları ve askerler kışlada kalırken Temmuz 1829 'da alt kattaki koğuşlarda yangın çıkmıştır. Yangına müdahale bakımından kışlada hayli noksanlıkların olduğu bu dönemde, sadece mevcut bir tulumba ile alevler söndürülmeye çalışılmıştır. Tüm bu imkânsızlıklara rağmen Bostancıbaşı Osman Ağa’nın etkili tedbirleriyle söz konusu yangın fazla büyümeden söndürülebilmiştir. ${ }^{90}$

II. Mahmud yaklaşık üç ay boyunca Tarabya'daki yalıda kalmış, Boğaz civarındaki kaleleri teftiş ederek Rus öncü birliklerinin bu bölgelere sarkmalarını engellemek amacıyla askeri ve mülki erkânı teyakkuz halinde tutmuştur. Rus tehdidinin ortadan kalkmasıyla padişah 10 Ağustos 1829'da Râmî Kışlası'na dönüş kararı almış, yine gösterişli bir merasim ve beş buçuk saatlik bir yolculuktan sonra

\section{Târih-i Livâ, s. 14-15.}

88 Târih-i Livâ, s. 73-74; Lütfi, Tarih, II, s. 70; Letâif-i Enderûn, s. 461. Bu arada Eyüp Defterdar İskelesi'nde Beyhan (Peykhan) Sultan Sarayı'nda bulunan padişahın haremi de Emirgan'daki Gümrükçü Osman Paşa yalısına nakledilmiştir (Târih-i Livâ, s. 75).

89 Hızır İlyas Efendi, Letâif-i Enderûn, s. 461-462, 466; Târih-i Livâ, s. 74-75.

90 Lütfi, Tarih, II, s. 164. 
Sancak-1 Şerif Râmî Kışlası'na nakledilerek kuleye dikilmiş ve askerler de tabyalara yerleştirilmişlerdir. ${ }^{91}$

1829 yazı sonlarında Rumeli cephesinden gelen mağlubiyet haberleri, kışlada büyük üzüntü yaratmıştı. Buna mukabil askerin moralini yüksek tutmaya çalışan ve manevi tedbirleri de ihmal etmeyen ${ }^{92}$ II. Mahmud, zaman zaman atına binerek "haydârâne" bir eda ile kışla meydanına sürmüş ve herkesin şevkle savaş talimi yapmalarını emretmek suretiyle bu kasvetli havayı dağıtmaya çalışmıştır. Maiyetindeki Hızır İlyas Ağa’nın naklettiğine göre Padişahın bu tür manevralarıyla gayrete gelen süvariler Râmî Kışlası ile Davudpaşa sahrası arasında büyük savaş talimleri icra etmişlerdir. ${ }^{93}$

İdari ve askeri bir üs oluşunun yanında Râmî Kışlası'nın bir diğer önemli özelliği, II. Mahmud'un kıyafet alanında yaptığı yeniliklerin vitrini olmasıdır. 1826 yazında Asâkir-i Mansûre Ordusu kurulduktan sonra neferlerin kıyafetlerinde değişiklik yapılmış, talimli askerlere fes, üniforma ve kalavra denilen ayakkabılar giydirilmişti. ${ }^{94}$ Öncülük ettiği bu değişiklikleri halka tanıtmak ve yaygınlaştırmak amacıyla 14 Kasım 1828'de II. Mahmud Râmî Kışlası'ndan Topçular Camii'ne giderek ilk defa Cuma Selamlığı'na başında fes ve omuzlarında harvânî olduğu halde çımıştır. ${ }^{95}$ Ardından 15 Mart 1829'da yeni bir kararla Enderun halkının eski kıyafetlerinden olan kaftan, entari, çakşır vb. şeyleri terk etmelerini, bunların yerine püsküllü fes, Mısır kesimi cübbe, mintan ve şalvar giymelerini emretmiştir. ${ }^{96}$ Kıyafet konusundaki son ve en kapsamlı adım olarak 6 Nisan-4 Mayıs 1829'da (evâhir-i Şevval 1244) ilmiye mensupları hariç devlet adamlarına kavuk veya kallavi yerine fes giyme hükmü ${ }^{97}$ ve sair elbiselerinde bir takım düzenlemeler getiren II. Mahmud, muhafazakâr-statükocu tepkilere ${ }^{98}$

91 Târih-i Livâ, s. 92-93; Letâif-i Enderûn, s. 469-470; Lütfi, Tarih, II, 95.

92 Târih-i Livâ, s. 94 vd.

93 Letâif-i Enderûn, s. 472.

94 Çelik, a.g.e, s. 306-313.

95 Târih-i Livâ, s. 26-27. 6 Şubat 1829'da kışla camiinde yapılan Cuma selamlığına yine fes ve harvani ile katılan padişah, başında şal sarılı imam efendinin sakil göründüğünü ifade ederek derhal fes ve harvani giymesini irade etmiştir. Abdülhak Molla "cümlemiz yek-reng olduk" dediğine göre padişahın maiyetindekilerin tamamı bu şekilde kıyafetlerini tanzim etmişlerdi (Tarih-i Livâ, s. 49).

96 Letâif-i Enderûn, s. 457-458.

97 Lütfi, Tarih, II, s. 148. İlgili nizamname için bkz. a.g.e. II, 18 numaralı zeyl.

98 Lütfi, Tarih, II, s. 169. Mesela II. Mahmud Râmî Kışlası’nda iken müderris Boşnak Mustafa Efendi, Ramazan ayında Eyüp Camii'nde verdiği vaazlarda kıyafet alanında 
aldırmayarak bu konuda tavizsiz bir tutum sergilemiştir. Bunu yaparken Râmî Kışlası'nda her an ordusuyla sefere çıkmaya hazır bir padişah konumunda olması işini kolaylaştırmıştır. ${ }^{99} \mathrm{Bu}$ sürecin sonraki adımları, yurtiçi gezilerde yeni kıyafetleri tanıtmak ve beraberinde götürdüğü bir başka yenilik olan ve İtalyan Maestro Giuseppe Donizetti tarafından eğitilen Mızıka-i Hümayun'u halka dinletmek olmuştur. ${ }^{100}$

1829 Haziran ayından itibaren birkaç bölgede Serdar-1 ekrem Reşid Mehmed Paşa'nın direniş göstermesine rağmen; Rahova, Pravadi, Silistre ve nihayet İslimye'nin peyderpey düşmesiyle Ruslara Edirne yolu açılmıştı. Bundan başka İngiltere, Fransa ve Rusya’nın bağımsız bir Yunanistan kurulması konusunda Bâbıâli'ye baskı hususunda uzlaşmaları, Osmanlı İmparatorluğu'nu iyice köşeye sıkıştırmıştı. Edirne ve dolayısıyla İstanbul yolunun Ruslara açılması karşısında sevk edebileceği askeri kuvveti kalmayan Bâbbâli, 15 Ağustos 1829'da İngiltere ve Fransa elçilerinin ortak notasını kabul etmek zorunda kalmıştır. Bu dönemde Rusların İstanbul üzerine yürüyebilecekleri ihtimali gündeme gelince, Râmî ve Davudpaşa kışlaları civarına bir takım tabya ve istihkâmlar yapılmıştır. Günümüzde o bölgede semt adları olan Yıldız Tabya, Karlıtepe ve Demirkapı tabyaları o vakit inşa edilmişlerdir. ${ }^{101}$

yapılan yenilikleri şiddetle tenkit etmiş ve buna neden olanları tekfir etmiştir. Bu haber alınınca hakkında sürgün kararı çıkmış o da Aydın'da Adalar kasabasında kendisi gibi kıyafet değişikliğini kâfirlikle eş tutan ve yaptığı propaganda sonucunda başına hatırı sayılır kalabalık toplayan Keleş Mehmed'in yanına iltica etmiştir.

99 Vakanüvis Lütfi Efendi'nin zeyiller kısmında verdiği 11 Nisan 1829 tarihli nizamname suretinde II. Mahmud'un bu kıyafet değişikliğini muhaliflerin argümanları üzerine oturtması oldukça ilgi çekicidir. Dini öğelerin ustalıkla kullanıldığı bu nizamnamede uzun süre merkezde oturan ve hazariyete alışan devlet adamlarının cihad ve gazayı unuttuğundan süs ve ihtişama merak sardığı, zahiri elbiseden ziyade takva elbisesinin önemli olduğu ve yapılan bu tür yeniliklerin yegâne maksadının şu an itibarıyla teşebbüs edilen gaza ve sefer halinden (usul-ı bedeviyetin iltizamından) kaynaklandığı ifade edilmiştir, bkz. Lütfi, Tarih, II, s. 269-273, 18 numaralı zeyl. Genel olarak XVIIIXIX. yüzyılda kıyafet düzenlemeleri ve II. Mahmud'un bu alanda takip ettiği strateji için ayrıca bkz. Donald Quataert, "Clothing Laws, State and Society in The Ottoman Empire (1720-1829), International Journal of Middle Eastern Studies, XXIX (1997), s. 403-425.

100 Abdülkadir Özcan, "II. Mahmud'un Memleket Gezileri”, İstanbul Üniversitesi Edebiyat Fakültesi Dergisi -Prof. Dr. Bekir Kütükoğluna Armăgan Sayısı-, (İstanbul: Edebiyat Fakültesi Basımevi, 1991), s. 361-379; Mehmed Dâniş Bey, Netîcetül-Vekāyi‘, s. 37. 101 Mehmet Nermi Haskan, Eyüp Tarihi, (İstanbul: TURİNG, 1993), II, s. 78. 
Edirne'de yapılan umumi meşverette, Ruslara karşı muharebe etmeme kararı alınmış ve gönderilen heyet marifetiyle Rusların talepleri öğrenildikten sonra 22 Ağustos 1829 'da Edirne teslim edilmişti. Bu durum karşısında zorunlu olarak barış isteyen Bâbıâli delege olarak Sadık Efendi ve Eminbey-zâde Abdülkadir Bey'i Edirne’deki Rus karargâhına göndermiştir. Osmanlı delegeleri müzakerelerin ardından muhatapları olan Kont Alexis Orloff ve Kont F. de Pahlen tarafindan adeta dikte edilen şartları imzalayarak 14 Eylül 1829 'da başkente dönmüşlerdi. ${ }^{102}$

Bâbıâli'de yapılan müzakerelerin ardından Padişahın da onayı ile Edirne'de yapılan barış görüşmelerinde Rusların öne sürdüğü ağır şartları hafifleterek daha makul bir antlaşma imzalanmasını sağlamak amacıyla son derece kıymetli hediyelerle Halil Rufat Paşa, Süleyman Necib Efendi ve Sarım Efendi'den oluşan elçilik heyetinin Petersburg'a gönderilmesi kararlaştırılmıştı. Gerekli hazırlıklar tamamlandıktan sonra Ekim 1829'da söz konusu heyet Râmî Kışlası'nda padişah tarafından kabul edilerek nihai talimatlar verilmiştir. ${ }^{103}$

Edirne'de yapılan barış görüşmeleri nihayete erdikten sonra, müzakere sürecinde Rusyảnın başdelegesi olan Kont Alexis Orloff'un İstanbul'a geleceği haber alınmıştı. Bunun üzerine mihmandarlığına Miralay Reşid Bey atanarak ağırlanması konusunda gereken hassasiyetin gösterilmesi istendi. Kont Orloff İstanbul'a vardıktan sonra elçilik tercümanı Frankini'nin müracaatı üzerine, II. Mahmud reisülküttaba kışlaya gelmesi talimatı göndermiş, ardından Orloff 5 Aralık 1829'da birkaç diplomatla Râmi Çiftliği Kışlası'nda padişah tarafından kabul edilmiştir. ${ }^{104}$

Hemen akabinde Râmî Kışlası'nda kabul edilen bir diğer isim Ağa Hüseyin Paşa olmuştur. Aralık 1829'da, Rus kuvvetlerini Şumnu'ya sokmayan Ağa Hüseyin Paşa'nın başarısı takdir edilmiş, barış antlaşmasının imzalanmasından sonra merkeze dönmesine dair irade çıkmıştı. 17-27 Aralık 1829'da (evâhir-i C 1245) İstanbul'a ulaşan Ağa Hüseyin Paşa Râmi Kışlası'nda huzura kabul edilmiş ve padişahla birlikte kışla meydanında süvarilerin icra ettikleri talimleri izlemiştir. ${ }^{105}$

14 Eylül 1829'da imzalanan Edirne Antlaşması ile Osmanlı-Rus Savaşı resmen bitirilmesine rağmen II. Mahmud hemen Râmî Kışlası'ndan ayrılmamıştı.

102 Lütfi, Tarih, II, s. 80-105; Şerafettin Turan, "Edirne Antlaşması, AÜDTCFD, IX/1-2, (1951), s. 111-151; Turan, "Edirne Antlaşması", TDVIA, X, s. 442-443).

103 Lütfi, Tarih, II, s. 119-120.

104 BOA, HAT, nr. 1049/43268; Târîh-i Livâ, s. 108; Lütfi, Târîh, II, 125-126; Letâif-i Enderûn, s. 478-479.

105 Letâif-i Enderûn, s. 478. 
Bu dönemde hem avlanmak hem de dinlenmek maksadıyla 16 Ocak 1830'da kışladan ayrılarak vapurla Büyükçekmece'ye gitmiş, avlanma bittikten sonra beraberinde getirdiği mızıka takımını akşam erkek-kadın köydeki ahaliye dinletmiştir. Ardından Küçükçekmece'ye geçen padişah Barutçubaşı Arakel'in evine misafir olduktan sonra karadan yine Râmî Kışlası’na dönmüştür. ${ }^{106} \mathrm{Bu}$ arada 27 Ocak 1830'da Topkapı Sarayı'nda yapılan deve güreşlerini kaçırmak istemeyen padişah, günü birlik Suriçi'ne girdikten sonra akşam yine kışlaya dönmüştür. ${ }^{107} \mathrm{Bu}$ dönemde kışlada ikametini sürdüren padişahı sevindiren yegâne gelişme ise 9 Şubat 1830'da bir şehzadenin doğum müjdesiydi. Edirne Antlaşması'nın dayattığı ağır şartların kasvetli atmosferini dağıtmak ve Şehzade Abdülaziz in doğumunu kutlamak amacıyla Râmî Kışlası'nda yedi gün yedi gece şenlik yapılmıştır. Kutlamalarda meddah, rakkas ve çengiler ile gölge oyunları izlenmiştir. ${ }^{108}$

II. Mahmud'un ikametini sürdürmesi nedeniyle Râmî Kışlası'nın idari ve askeri bir üs olma vasfı devam etmekteydi. Dolayısıyla çeşitli merasimler ve devlet adamlarının kabulleri kışlada gerçekleştirilmiştir. Bu cümleden olarak 1829 yılındaki gibi ${ }^{109} 1830$ yılı Ramazan Bayramı (25 Mart 1830) için devlet erkânı padişahla bayramlaşmak üzere topluca Râmi Kışlası'na gitmişlerdir. Bu arada seferberlik nedeniyle muayede teşrifatının bir kısmı uygulanmamıştır. ${ }^{110}$

Rusya ile barış antlaşması imzalanmış olduğundan, Edirne'de bulunan Serdar-1 ekrem Reşid Mehmed Paşa, Miralay Ahmed Bey aracilı̆̆ıyla İstanbul'a davet edilmişti. 10 Nisan 1830'da Râmi Kışlası'nda padişah tarafından kabul edilen Serdar-1 ekrem, görüşmenin ardından hususi bir merasimle Bâbıâli'ye uğurlanmıştır. On gün kadar dinlenen Reşid Mehmed Paşa tekrar Râmi Kışlası'na gidip padişaha veda ziyaretinde bulunmuş ve mevcut antlaşmaya rağmen Rusya ile savaşın yeniden başlaması ihtimaline binaen Edirne'deki ordunun başına dönmüştür. ${ }^{11}$ Keza savaş nedeniyle Fransa elçisi gibi İstanbul'u terk eden Rusya elçisi Ribopierre tekrar döndüğünde, getirdiği resmi evrakı ve itimatnâmesini padişaha arz etmek istemiş, sadaret kaymakamlığıyla elçiliğin temasları neticesinde Ribopierre Râmi Kışlası'nda huzura kabul edilmiştir. ${ }^{12}$

106 Netîcetüll-Vekāyi“, s. 33; Târih-i Livâ, s. 121-122.

107 Târih-i Livâ, s. 123.

108 Târih-i Livâ, s. 125-126; Letâif-i Enderûn, s. 483.

109 Letâif-i Enderûn, s. 458-59.

110 Lütfi, Târîh, II, s. 180.

111 Lütfi, Târîh, II, s. 182, 191; Letâif-i Enderûn, s. 489.

112 BOA, HAT, nr. 1164/46079-C. 
Öte yandan Rusya ile patlak veren savaştan istifadeyle adeta diplomatik abluka uygulayan İngiltere ve Fransa’nın nüfuz mücadelesine, bu dönemde Avusturya da katılmıştır. Askeri reform sürecine yapacağı somut katkılarla rakiplerinin bir adım önüne geçeceğini düşünen Avusturya Şansölyesi Prens Metternich, Bâbıâli ile ilişkilerini en üst seviyede tutmaya özen göstermekteydi. Bu ilginin tezahürlerinden biri olarak Mart-Nisan 1830 'da sandıklar dolusu hafif süvari üniforması ve bir miktar askeri teçhizatla birlikte Avusturyalı Albay Comte Malaguzzeny'yi İstanbul'a göndermiştir. Malaguzzeny söz konusu askeri malzeme ve teçhizatı Râmi Çiftliği Kışlası'nda Sultan’a bizzat takdim etmiştir. Albay Malaguzzeny, bu esnada padişahın kışlada on binden fazla askerin başında ve tam teçhizatlı bir vaziyette "korkusuzca Rusları beklediğini", savaşa taraftar olmayan "kendini bilmez" bazı isyankâr subayların, muhalif tavırlarının bedelini hayatıyla ödediğini iddia etmiştir. ${ }^{113}$

Henüz iç güvenlik risklerinin tam olarak ortadan kalkmadığını düşünen, keza Rusya ile savaşın tekrar başlama ihtimalini göz ardı etmeyen ve bu nedenle kışladaki ikametini uzatan II. Mahmud savaş ihtimalinin zayıflamasının ardından Topkapı Sarayı'na dönme kararı almıştır. Hazırlıkların ardından yine gösterişli bir merasimle 25 Mayıs 1830'da Müneccimbaşının belirlediği uğurlu saatte Sancak-1 Şerif Râmî Kışlası'ndan alınarak Topkapı Sarayı'na nakledilmiş ve Hırka-i Saadet Odası'na konulmuştur. Ardından bir süre dinlenen padişah Tarabya mevkiine giderek oradaki süvarileri ve mızıkacıları maiyetine alarak Topkapı Sarayı'na dönmüştür. ${ }^{114}$ Böylelikle 15 Eylül 1828'de Ruslarla savaş nedeniyle seferberlik kararı alarak sarayı terk eden ve Râmî Kışlası'na yerleşen II. Mahmud, 617 gün boyunca istisnai bazı haller dışında kışlayı devletin idari ve askeri üssü olarak kullanmış, başta kıyafet bahsi olmak üzere bir takım reform adımlarını seferberlik pozisyonundan aldığı güçle ciddi bir mukavemet ve muhalefetle karşılaşmadan yürürlüğe koyabilmiştir.

Râmî Kışlası II. Mahmud'un halefleri dönemlerinde de önemini korumuştur. Tanzimat Fermanı'nın (3 Kasım 1839) ilanın ardından, söz konusu fermanda yer alan askerlikle ilgili hususların hayata geçirilmesi konusunda önemli adımlar

113 Colonel Comte Malaguzzeny'nin Prens Metternich'e sunduğu rapor, Avusturya Devlet Arşivi (Österreichisches Staatsarchiv, Wien), Türkei, HHSa, nr. VI/17, s. 8.

114 Târih-i Livâ, s. 142-143; Lütfi, Tarih, II, s. 193; Letâif-i Enderûn, s. 489-490. Hızır İlyas Efendi, padişahın 3 Z 1245/26 Mayıs 1830'da Râmî Kışlası'ndan ayrıldığını ifade ediyor, buna mukabil Lütfi Efendi ve Abdülhak Molla ise 2 Z 1245/25 Mayıs 1830 tarihini vermişlerdir. 
atılmaya başlanmıştır. Bu süreçte Sultan Abdülmecid'in zaman zaman askeri tesisleri teftiş ettiği bilinmektedir. Bu yerler arasında Râmî Çiftliği Kışlası da mevcuttur; 3 Şubat 1844'de gerçekleşen teftişte, padişah koğuşlar dâhil tüm kışlayı denetlemiş ve teamüllerin dışında bir uygulama olarak memnuniyetini ifade etmek üzere askere hitaben bir de konuşma yapmıştır. ${ }^{115}$ Abdülmecid'in Râmî Kışlası'nı bir sonraki teftişi Haziran 1850 sonlarındaydı, bu ikinci teftişten de memnun kalan Padişah görevlileri ödüllendirmiştir. ${ }^{116}$

Rusya’nın, politik emellerini gerçekleştirmek amacıyla 1848 'den itibaren bilinçli olarak yarattığı sorunların krize dönüşmesinin ardından 22 Haziran 1853 'te Prut nehrini geçerek Osmanlı topraklarına girmesiyle, Bâbıâli kendisini yeni bir savaşın içinde bulmuştur. 25 Eylülde yapılan umumi meşveretin ardından 4 Ekim 1853 'te Rusya'ya resmen savaş ilan edilmiş, Rusya'nın geri adım atmaması karşısında çıkarlarını tehlikede gören İngiltere ve Fransa’nın Bâbıâli'ye yaklaşmalarıyla 12 Mart 1854 'te üçlü bir ittifak antlaşması imzalanmıştır. Bu ittifak antlaşması büyük bir sevinç yaratmış ve Rusya’ya karşı zafer elde edileceği konusunda ahali ümitlenmiştir. Bu seferberlik havası içinde ülkenin her yerinden yardımlar yağmaya başlamış, İstanbul'da varlıklı ailelerin haremlerinde dahi cephedeki askerler için çamaşırlar dikilmiştir. Anadolu'dan silaha sarılarak İstanbul'a gelen gönüllüler Selimiye Kışlası'na yerleştirilerek burada birkaç gün dinlendirildikten sonra birkaç yüz kişilik kafileler halinde Tophane ve Galata yolu ile Beyazıt'taki seraskerlik makamına getirilmiştir. Törenle karşılanan gönüllü birlikleri Dâr-1 Şûrâ-yı Askerî müftüsünün dua merasiminin ardından Davudpaşa ve Râmî kışlalarına sevk edilmekte, hazırlıkların tamamlanmasının ardından da cepheye gönderilmekteydiler. ${ }^{117}$

Kırım Savaşı (1853-1856) sebebiyle Nisan 1854'ten itibaren İstanbul'a peyderpey gelmeye başlayan müttefik İngiliz ve Fransız askerleri devlete ait binalara yerleştirilmeye başlanmıştır. Daha sonra bu binalar yetmeyince biraz da müttefiklerin pervasız tutum ve keyfi taleplerini abartılı stratejik gerekçeler arkasına gizlemeleri nedeniyle özel mülklere yerleştirilmişlerdir. İstanbul'u adeta parselleyen müttefiklerden Fransizlara tahsis edilen yerler arasında Davudpaşa, Maltepe ve Râmî Çiftliği kışlaları da mevcuttu. ${ }^{118}$

115 Lütfi, Tarih, VII, s. 95 vd.

116 Vakanüvis Ahmed Lütfi Efendi Tarihi, Münir Aktepe (haz.), (İstanbul: Edebiyat Fakültesi Basımevi, 1984), IX, s. 32.

117 Mufassal Osmanlı Tarihi, VI, s. 3038-3039.

118 İngiliz Amiral Sir Adolphus Slade (Müşavir Paşa), o esnada İstanbul'da bulunduğundan 
Râmî Kışlası hakkında tashihe muhtaç olan bir diğer bilgi Kırım Savaşı esnasında buranın Sultan Abdülmecid tarafından karargâh olarak kullanıldığ 1 hususudur. Bazı müellifler bu bilgiyi hiçbir kaynak göstermeden hatalı olarak müteselsilen tekrarlamaktadır. ${ }^{119}$ Vakıa yukarıda belirtildiği üzere Sultan Abdülmecid, zaman zaman Râmî Kışlası'nı denetlemiştir, ${ }^{120}$ ancak bu tür teftişler Kırım Savaşı'na has olmadığı gibi devrin kaynaklarında ve arşiv kayıtlarında burayı karargâh olarak kullandığına dair herhangi bir bilgiye rastlanmamıştır. Bilakis Râmî ve Davudpaşa kışlaları Kırım Savaşı esnasında müttefik Fransız askerlere tahsis edilmiştir. ${ }^{121}$ Dolayısıyla padişahın yabancı askerleri denetlemesi veya onların meskûn olduğu askeri tesisleri karargâh olarak kullanması da mümkün değildir. Râmî Kışlası yukarıda ayrıntıları ile aktarıldığı üzere 1828-29 Osmanlı-Rus Savaşı esnasında II. Mahmud tarafindan 15 Eylül 1828-25 Mayıs 1830 arasında 617 gün süreyle karargâh olarak kullanılmış, dahası Padişahın maiyetiyle kışlaya taşınması ve yaklaşık iki yıl burada kalmasıyla, bir anlamda Topkapı Sarayı'nın işlevini yüklenmiştir. II. Mahmud'un Râmî Kışlası'nda geçirdiği döneme dair arşiv belgeleri ve bu süreci gün be gün ayrıntılarıyla nakleden çağdaş kaynaklar ${ }^{122}$ mevcutken, bunlardan haberdar dahi olmayan araştırmacıların burayı Abdülmecid'in karargâhı yapmak gibi fahiş bir hataya düşmeleri sürpriz değildir.

II. Abdülhamid devrinde (hd.1876-1909) askeri fonksiyonunu sürdüren Râmî Kışlası zaman zaman salgın hastalıklar nedeniyle tahliye edilmiş, bazen de aynı tehlikeye maruz kalan diğer kışlalardan tahliye edilen askerlere ev sahipliği

müttefiklerin başkente ayak basmasından itibaren yaşanan olayları, müttefiklerin keyfi tutum ve suiistimallerini tüm ayrıntıları ile nakletmekte ve başkentte müttefiklerin hangi bölgelere yerleştiklerine dair önemli bilgiler vermektedir (Slade, Türkiye ve Kırm Harbi, s. 129-131, 213-217).

119 Tuğlacı, Osmanlı Mimarlı̆̆ında Batılılaşma Dönemi, s. 35; Doğdu, "Kışlalar”, Türkler, XII, s. 181; Ayşe Yetişkin Kubilay, "Râmî Kışlası", DBİA, VI, s. 306; Sibel Onat HattapNil Köroğlu, "Eyüp’te Önemli Bir Kültür Varlığı, Râmî Kışlası”, VIII. Eyüp Sultan Sempozyumu Tebliğler (7-9 Mayıs 2004), (İstanbul: Eyüp Belediyesi, 2004), s. 161.

120 Sultan Abdülmecid ilk olarak 3 Şubat 1844 'te maiyetinde askeri ve mülki erkân olduğu halde Râmî Kışlası'nı denetlemiş ve burada askere hitaben bir konuşma yaparak memnuniyetini dile getirmiştir (Lütfi, Tarih, VII, s. 95-96). Sultanın kışlayı ikinci kez denetlemesi ise Haziran 1850'de gerçekleşmiştir (Vak'anüvis Ahmed Lütfi Efendi Tarihi, IX, s. 32).

121 Slade, Türkiye ve Kırım Harbi, s. 217.

122 Hafız Hızır İlyas Efendi, Vekāyi'i Letâif-i Enderûniyye, (İstanbul: Dârü’t-TıbaâtülAmire, 1276); Abdülhak Molla, Târih-i Livâ, -Sultan II. Mahmud Portresinden Farklı Bir Kesit-, Mehmet Yıldız (haz.), (Ankara: Türk Tarih Kurumu, 2013). 
yapmıştır. Mesela 1893-94’te İstanbul'da yaşanan şiddetli kolera salgınında Davudpaşa ve Râmî kışlalarındaki askerler de hastalığa yakalanmışlardır. Bu iki kışlada durumun kontrol altına alınmasından sonra salgının Edirnekapı civarında bulunan Münzevi Kışlası'na sıçraması üzerine buradaki askerler Râmî Kışlası'na nakledilmişlerdir. ${ }^{123}$ II. Abdülhamid devrinde devlet adamlarının Râmî civarına iskânıyla bölgedeki nüfus yoğunluğu artmaya başlamış, Padişahın rical ve saray erkânına bu bölgede temlik ettiği arazilere, yeni sahipleri tarafından konaklar inşa edilmiş, bu suretle bölgedeki nüfus yoğunluğu kısa sürede Topçulara doğru kaymaya başlamıştır. Keza Şeyhülislam Üryânizâde Esad Efendi'nin tavsiyesi doğrultusunda 1877-78 Osmanlı Rus Savaşı (93 Harbi) nedeniyle Balkanlardan gelen göçmenler Râmî Çiftliği arazisi ve civarında imara açılan bölgelere yerleştirilmiş, böylece bugün Râmî Cuma Mahallesi olarak adlandırılan yerleşim bölgesi ortaya çıkmıştır.

Mondros Mütarekesi (30 Ekim 1918)'nin ardından 13 Kasım 1918'de fiilen İstanbul'u işgale başlayan İtilaf Devletleri 16 Mart 1920'de işgali resmileştirmişlerdi. İşgalci devletler başkenti belli bölgelere ayırarak stratejik yerlere konuşlanmışlardı. Bu paylaşımda Râmî Kışlası ve civarını Fransızlar işgal etmiş, kışlaya Cezayir'den getirdikleri tümeni yerleştirmişlerdi. Söz konusu işgal sonucunda Osmanlı ordusuna ait hayli silah ve mühimmat da Fransızların eline geçmişti. Ancak İstanbul'da gizlice örgütlenen vatanseverlerden oluşan Milli Müdafaa Grubu, Anadolu direnişine silah ve cephane temin etmek amacıyla Râmî Kışlası'ndaki mühimmatı gizlice tahliye etme kararı almıştır. İstanbul'un sayılı fırtınalarından Topkapılı Cambaz Mehmet ve şürekâsının gayret ve fedakârlıklarıyla buradaki silah ve cephanenin büyük kısmı Anadolu’ya kaçırılmıştır. ${ }^{124}$

Tarihsel süreç itibarıyla bölgedeki yerleşmenin çekirdeğini teşkil eden kışla, Cumhuriyet döneminde I. Ordu Komutanlığı'nın emrine verilmiştir. 28 Mayıs 1927 tarih ve 1057 sayılı "Türkiye Cumburiyeti Dâhilinde Bulunan bil-cümle Mebânî-i Resmiye ve Milliye Üzerindeki Tü̆ra ve Methiyelerin Kaldırlması” kanunu gereği kışlanın dört kapısı üzerinde bulunan kitabeler kazınmış ve kaldırılmıştır. 1971 yılına dek askeri amaçlı kullanılan kışla bu tarihte mülki idareye devredilmiştir. 1940-50 arasında Balkanlardan gelen ikinci göç dalgasıyla RâmîYeni Mahalle oluşmuştur. 1966-67 tarihli Râmî Sanayi Planı kapsamında küçük

123 Mesut Ayar, Osmanlı Devleti'nde Kolera, İstanbul Örneği (1892-1895), (İstanbul: Kitabevi, 2007), s. 186, 370-371.

124 Selahattin Salışık, Kurtuluş Savaşı̇nın Gizli Örgütü, İstanbul: Kaynak Yayınları, 1999; Salışık, "Râmî Kışlası Boşaltılıyor", Polis Dergisi, 279 (Eylül 1975), s. 29-31. 
ölçekli sanayi işletmelerinin bölgede artmaya başlaması ve bunun etrafında oluşmaya başlayan çarpık kentleşme, bölgenin tarihi dokusuna büyük zarar vermiştir. $\mathrm{Bu}$ sebeple semtin en önemli tarihi yapısı olan ve birinci sınıf tarihi eser statüsünde bulunan Râmî Kışlası da bu çarpık kentleşmenin ortasında kaderine terk edilmiştir. Râmî Kışlası ve müştemilatı, yerel yönetimlere yeni yetkilerin verildiği 1980'li yıllarda, Eyüp Belediye Meclisi'nin 13 Mayıs 1985'te aldığı bir kararla iki yıllığına kuru gıda toptancılarına tahsis edilmiştir. 21 Haziran 1990 tarih ve III Numaralı Koruma Kurulu kararıyla, kışla ve çevresinin "Râmî Kültür Merkezi” olarak tanımlanmasına rağmen, başlangıçta geçici kaydıyla belediye tarafından alınan karara istinaden gıda toptancılarının işgali altında kalmış ve epeyce tahribata uğramıştır. ${ }^{125}$ Uzun süre kaderine terk edilen kışlanın bugün Kültür Bakanlığı'nın inisiyatifiyle restore ediliyor olması sevindirici bir gelişmedir.

\section{Mahmud Devrinde İdari-Askeri Bir Üs: Rami Kışlası}

Öz — Bu makalede; Osmanlı askeri sisteminde yeniçeri odalarından Batı'da modern talimli ordular için inşa edilen kışla yapılarına geçiş süreci, bu bağlamda Vak’a-i Hayriyye'nin ardından 1826 'da yeni kurulan Asakir-i Mansure Ordusu için inşa edilen kışlalardan biri olan Rami Çiftliği Kışlası’nın yapım süreci ve özellikle Sultan II. Mahmud'un mülga yeniçeri ocağı bakiyesinin karşı darbe girişimlerinden korunmak, Rusya ile 1828 'de patlak veren savaşta cephedeki ordunun ve galeyan halindeki halkın moralini yükseltmek için attığı adımlar ve öte yandan giriştiği radikal reformlara karşı statükocu-muhalif çevrelere karşı kendisini güvenceye alan hünkârın 617 gün boyunca ikamet ettiği kışladaki resmi ve gündelik faaliyetleri ele alınmış, keza Rami Kışlası'nın muvakkaten idari-askeri bir üs haline gelmesinde rol oynayan hususlar değerlendirilmiş ve II. Mahmud döneminden günümüze dek kışlanın tarihinde vuku bulan önemli gelişmelere değinilmiştir.

Anahtar Kelimeler: Kışla, yeniçeri odaları, Rami Kışlası, Davudpaşa Kışlası, Osmanlı Mimarisi, II. Mahmud, meşta, Asakir-i Mansure Ordusu.

125 Mehmet Nermi Haskan, Eyüp Tarihi, II, s. 78-79; H. Fahrunnisa (Ensari) Kara, "Râmî", DBİA, VI, s. 305-306; Sibel Onat Hattap- Nil Köroğlu, "Eyüp'te Önemli Bir Kültür Varlığı, Râmî Kışlası”, VIII. Eyüp Sultan Sempozyumu, s. 162-163; Zühal Çetiner Doğdu, "Kışlalar”, Türkler, XII, s. 181-182. 


\section{Kaynakça}

\section{Arşiv Kaynakları}

a. Başbakanlık Osmanlı Arşivi

b. Topkapı Sarayı Müzesi Arşivi

c. Avusturya Devlet Arşivi, (Österreichisches Staatsarchiv, Wien), Türkei, HHSa, nr. $\mathrm{VI} / 17$.

\section{Yazmalar, Araştırma ve İnceleme Eserler}

Abdülhak Molla: Târih-i Livâ, -Sultan II. Mahmud Portresinden Farklı Bir Kesit- Mehmet Yıldız (haz.), Ankara: Türk Tarih Kurumu, 2013.

Ahıshalı, Recep: "Râmi Mehmed Paşa", Türkiye Diyanet Vakfı İlâm Ansiklopedisi (TDVİA), XXXIV, s. 449-451.

Ahmed Cevad: Târîh-i Askerî̀-i Osmânî, II/IV, İstanbul Üniversitesi Tarih Yazmaları, nr. 4178.

: Târîh-i Askerî-i Osmânî, I, İstanbul 1299.

Ahmed Lütfi Efendi: Târîh-i Lütfî, I-VIII, İstanbul: Matbaa-i Amire, 1290-1328.

Akdağ, Mustafa: "Yeniçeri Ocak Nizamının Bozulması", AÜDTCF. Dergisi, V/3 (1947), s. $295-300$.

Anonim Osmanlı Tarihi (1099-1116/1688-1704), Abdülkadir Özcan (haz.), Ankara: Türk Tarih Kurumu, 2000.

Aşkun, İlgi Yüce-Sezgin, Haluk: "Râmi Kışlası Hakkında”, Tasarım Dergisi, 5/48, s. 85-86.

Ayar, Mesut: Osmanlı Devleti’nde Kolera, İstanbul Örneği (1892-1895), İstanbul: Kitabevi, 2007.

Baykal, Bekir Sıtkı: "Râmî Mehmed Paşa”, İslam Ansiklopedisi, IX, s. 623-624.

Beydilli, Kemal: "Islahat”, TDVIA, XIX, s. 170-185.

: "Küçük Kaynarca'dan Tanzimat'a Islahat Düşünceleri”, İlmi Araştırmalar, VIII (1999), s. 25-64.

: "Halil Hamid Paşa", TDVİA, XV, s. 316-318.

: "Yeniçeri", TDVIA, XLIII, s. 450-462.

: Osmanl Döneminde Imamlar ve Bir Imamın Günlüğ̈̈, İstanbul: Tarih ve Tabiat Vakfi, 2001.

Câbi Ömer Efendi: Câbî Târîhi, I, Mehmet Ali Beyhan (haz.), Ankara: Türk Tarih Kurumu, 2003.

Can, Selman: "Osmanlı Mimarlık Teşkilatının XIX. Yüzyıldaki Değişim Süreci ve Eserleri ile Mimar Seyyid Abdülhalim Efendi”, doktora tezi, İstanbul Üniversitesi, 2002. 
: Bilinmeyen Aktörleri ve Olayları ile Son Dönem Osmanlı Mimarlğğ, İstanbul: Erzurum İl Kültür ve Turizm Müdürlüğü, 2010.

: "XIX. Yüzyılda Osmanlı Mimarlığının Teşkilat Yapısı ve Balyanlar", 150. Yılında Dolmabahçe Sarayı Uluslararası Sempozyumu (23-2 Kasım 2006), Kemal Kahraman (ed.), İstanbul: TBMM Milli Saraylar Daire Başkanlığı, 2007, I, s. 64-78.

Çelik, Yüksel: Şeybül-Vüzerâ Koca Hüsrev Paşa-II. Mahmud Devrinin Perde Arkası-, Ankara: Türk Tarih Kurumu Yayını, 2013.

: "Mit ve Gerçek Arasında: Taksim Topçu Kışlası (Beyoğlu Kışla-i Hümayunu)" Osmanli İstanbul'u III, Uluslararası Sempozyum (25-26 Mayıs 2015), Feridun M. Emecen, Ali Akyıldız, Emrah Safa Gürkan (haz.), İstanbul: 29 Mayı Üniversitesi, 2015, s. $443-476$.

: "Serasker", TDVIA, XXXVI, 547-49.

Çetiner, Zühal: "Davutpaşa Kışlası ve İstanbul Kışlaları İçindeki Yeri”, yüksek lisans tezi, Yıldız Teknik Üniversitesi, İstanbul 1996.

Çiftçi, Aynur: “19. yüzyılda Osmanlı Devleti’nde Askeri Mimari ve İstanbul'da İnşa Edilen Askeri Yapılar”, I-II, (doktora tezi, Yıldız Teknik Üniversitesi, İstanbul, 2004).

Çiftçi, Aynur-Seçkin, Nadide: "19. Yüzyılda İstanbul'da İnşa Edilen Askeri Yapıların Koruma Sorunları”, Yildız Teknik Üniversitesi Mimarlık Fakültesi e-Dergisi, I/1 (2005), s. 51-66.

Defterdar Sarı Mehmed Paşa: Zübde-i Vekāyiâat, Abdülkadir Özcan (haz.), Ankara: Türk Tarih Kurumu, 1995.

Doğdu, Zühal Çetiner: "Kışla Mimarisi", Türkler, H.C. Güzel, K. Çiçek, S. Koca (ed.), Ankara: Yeni Türkiye Yayınları, 2002, XII, s. 178-189.

Doğru, Halime: Osmanlı Imparatorluğu’nda Yaya-Müsellem-Taycı Teşkilatı, (XV. ve XVI. Yüzyılda Sultanönü Sancağı), İstanbul: Eren Yayınları, 1990.

Emecen, Feridun: "Osman II", TDVIA, XXXIII, s. 453-456.

Eren, Ahmet Cevat: Mahmud II. Zamanında Bosna-Hersek, İstanbul: Nurgök Matbaası, 1965.

Ergin, Osman Nuri: Mecelle-i Umûr-ı Belediye, II, İstanbul: İBB Yayınları, 1995.

Evliya Çelebi Seyahatnamesi: İstanbul, Yücel Dağlı-S.Ali Kahraman (haz.), I/1, İstanbul; Yapı Kredi Yayınları, 2004.

Georg Oğulukyan’ın Ruznamesi, 1806-1810 İsyanlar-III. Selim, IV. Mustafa, II. Mahmud ve Alemdar Mustafa Paşa, Hrand D. Andreasyan (çev. ve notlar), İstanbul: Edebiyat Fakültesi Basımevi, 1972.

Goodwin, Godfrey: Yeniçeriler, Derin Türkömer (çev.), İstanbul: Doğan Kitap, 2001.

Gökyay, Orhan Şaik: “II. Osman'ın Şehadeti”, Atsız Armağanı, Erol Güngör vd, İstanbul: Ötüken Yayınları, 1976, s. 187-256. 
Hafız Hızır İlyas Efendi: Vekāyi'-i Letâif-i Enderûniyye, İstanbul: Dârü’t-Tıbaâtü’l-Amire, 1276.

Haskan, Mehmet Nermi: Eyüp Tarihi, II, İstanbul: Turing, 1993.

İlgürel, Mücteba: "Yeniçeriler”, İslam Ansiklopedisi, XIII, s. 385-395.

İncicyan, P. Ğ.: XVIII. Asırda İstanbul, H. Andreasyan (çev.), İstanbul: Baha Matbaası, 1976.

Kâmil Paşa: Târîh-i Siyâsî-i Devlet-i Aliyye-i Osmâniye, III, İstanbul: Matbaa-i Ahmed İhsan, 1327.

Kara, H. Fahrunnisa (Ensâri): "Rami”, Dünden Bugüne İstanbul Ansiklopedisi, VI, s. 305-306.

Karal, Enver Ziya: Osmanlı Tarihi, V, Ankara: Türk Tarih Kurumu, 1988.

Keçeci-zâde İzzet Molla: Dîvânçe-i İzzet-i Nâdîde-Güftâr be-Nâm-ı Hazân-ı Âsâr, İstanbul: Takvimhâne-i Âmire, 1257.

Kuban, Doğan: Osmanlı Mimarisi, İstanbul: YEM Yayınları (Yapı-Endüstri Merkezi), 2007.

Kubilay, Ayşe Yetişkin: “Kışlalar”, Dünden Bugüne İstanbul Ansiklopedisi, V, s. 7-8. : "Rami Kışlası", Dünden Bugüne İstanbul Ansiklopedisi, VI, s. 306.

Mutlu, Şamil: Yeniçeri Ocağının Kaldırılışı ve II. Mahmud'un Edirne Seyahati, Mehmed Dâniş Bey ve Eserleri, İstanbul: Edebiyat Fakültesi Basımevi, 1994.

Mufassal Osmanlı Tarihi, IV, V, VI, İstanbul 1960.

Murphy, Rhoads: "The Functioning of The Ottoman Army under Murad IV (16231639): Key to the Understanding of the Relationship between Center and Periphery in Seventeenth Century Turkey, Ph.d, Chicago University, 1979.

Mustafa Nuri Paşa: Netâyicü’l-Vukū'ât, III-IV, Neşet Çağatay (haz.), Ankara: Türk Tarih Kurumu, 1992.

Nüzhet, Sadettin: Rami Paşa Hayatı ve Eserleri, İstanbul: Kanaat Kütüphanesi, 1933.

Özcan, Abdülkadir: “Osmanlı Askeri Teşkilatı”, Osmanlı Devleti ve Medeniyeti Tarihi, Ekmeleddin İhsanoğlu (ed.), İstanbul: IRCICA, 1994, I, s. 337-371.

: “II. Mahmud'un Memleket Gezileri”, Prof. Dr. Bekir Kütükoğlu’na Armă̆an, İstanbul: Edebiyat Fakültesi Basımevi, 1991, s. 361-379.

Parmaksızoğlu, İsmet: "Rami Mehmed Paşa”, Türk Ansiklopedisi, XXVII, s. 220.

Petrosyan, Irina: “Osmanlı İmparatorluğu’nda Askeri Reformlar Konusunda İlk Girişim: XVI. Yüzyılın Sonu ile XVII. Yüzyılın Başında Yeniçeri Ocağı”, Osmanlı, Güler Eren (ed.), Ankara: Semih Ofset, 1999, VI, s. 673-683.

Quataert, Donald: "Clothing Laws, State and Society in The Ottoman Empire (17201829)", International Journal of Middle Eastern Studies, XXIX (1997), s. 403-425. 
Ramazanoğlu, M. Gözde: Osmanlı Yenileşme Hareketleri İçerisinde Selimiye Kışlası ve Yerleşim Alanı, doktora tezi, Yıldız Teknik Üniversitesi, İstanbul 2003.

Sahaflar Şeyhi-Zâde Esad Efendi: Üss-i Zafer, İstanbul: Süleyman Efendi Matbaası, 1293.

Sakaoğlu, Necdet: "Yeni Odalar”, Dünden Bugüne İstanbul Ansiklopedisi, VII, s. 467-468. : "Eski Odalar”, Dünden Bugüne İstanbul Ansiklopedisi, III, s. 203-204.

Salışık, Selahattin: "Rami Kışlası Boşaltılıyor”, Polis Dergisi, 279 (Eylül 1975), s. 29-31. : Kurtuluş Savaşı’nın Gizli Örgütü, İstanbul: Kaynak Yayınları, 1999.

Sarıcaoğlu, Fikret: Kendi Kaleminden Bir Padişahın Portresi, Sultan Abdülhamit (17741789), İstanbul: Tarih ve Tabiat Vakfi, 2001.

Sertoğlu, Mithat: IV. Murat, Ankara: T.C. Kültür ve Turizm Bakanlığı Yayınları, 1987.

Onat Hattap, Sibel-Köroğlu, Nil: "Eyüp’te Önemli Bir Kültür Varlığı, Rami Kışlası”, VIII. Eyüp Sultan Sempozyumu Tebliğler (7-9 Mayıs 2004), İstanbul: Eyüp Belediyesi, 2004, s. 160-163.

Slade, Adolphus (Müşavir Paşa): Türkiye ve Kırım Harbi, Ali Rıza Seyfi (çev.), İstanbul: Genelkurmay X. Şube Yayınları, 1943.

: Türkiye Seyahatnamesi, Ali Rıza Seyfioğlu (çev.), İstanbul: Askeri Deniz Matbaası, 1945.

Taylesanizâde Hafiz Abdullah Efendi Tarihi, İstanbul'un Uzun Dört Yilı (1785-1789), I, Feridun M. Emecen (haz.), İstanbul: Tarih ve Tabiat Vakfı, 2003.

Tuğlacı, Pars: Osmanlı Mimarlığında Batılılaşma Dönemi ve Balyan Ailesi, İstanbul: İnk1lap ve Aka, 1981.

Tuncer, Faruk: "Davut Paşa Kışlası Yapıları”, EJOS, IV (2001), Proceedings of the $11^{\text {th }}$ International Congress of Turkish Art, Utrecht-Nederlande, (August 23-28, 1999/ XLIII), s. 1-24.

Turan, Şerafettin: "Edirne Antlaşması, AÜDTCF. Dergisi, IX/1-2 (1951), s. 111-151.

..: "Edirne Antlaşması", TDVİA, X, s. 442-443.

Uzunçarşılı, İsmail Hakkı: Kapıkulu Ocakları, I, II, Ankara: Türk Tarih Kurumu, 1988. : Çandarl Vezir Ailesi, Ankara: Türk Tarih Kurumu, 1988.

.: "Edirne Vakası", TDVIA, X, s. 445-446.

.: "Halil Hamid Paşa", İstanbul Üniversitesi Edebiyat Fakültesi Türkiyat Mecmuası, V (1936), s. 213-269.

.: Osmanlı Tarihi, III/II. kısım, Ankara 1988.

: Osmanl Tarihi, IV/II. kısım, Ankara 1988.

Ünver, A. Süheyl: "Yeniçeri Kışlaları”, Belleten, XL/160 (Ekim 1976), s. 589-601. 
II. MAHMUD DEVRINDE İDARİ-ASKERİ BİR ÜS: RAMİ KIŞLASI

Vakanüvis Ahmed Lütfi Efendi Tarihi, IX, Münir Aktepe (haz.), İstanbul: Edebiyat Fakültesi Basımevi, 1984.

Vakanüvis Esad Efendi Tarihi, Ziya Yılmazer (haz.), İstanbul: Osmanlı Araştırmaları, 2000. Yeniçeri Kışlaları, İstanbul: Şehremaneti Matbaası,1929. 